\title{
Technology and factors influencing Greek-style yogurt - a Review
}

\section{Ignace Lange ${ }^{1}$, Stanisław Mleko ${ }^{2}$, Marta Tomczyńska-Mleko ${ }^{3}$, Galyna Polischuk ${ }^{4}$, Piotr Janas ${ }^{2}$, Lech Ozimek ${ }^{1}$}

\author{
1 - University of Alberta, Edmonton, Canada \\ 2 - University of Life Sciences in Lublin, Lublin, Poland \\ 3 - Institute of Plant Genetics, Breeding and Biotechnology, University of Life Sciences in \\ Lublin, Lublin, Poland \\ 4 - National University of Food Technologies, Kyiv, Ukraine
}

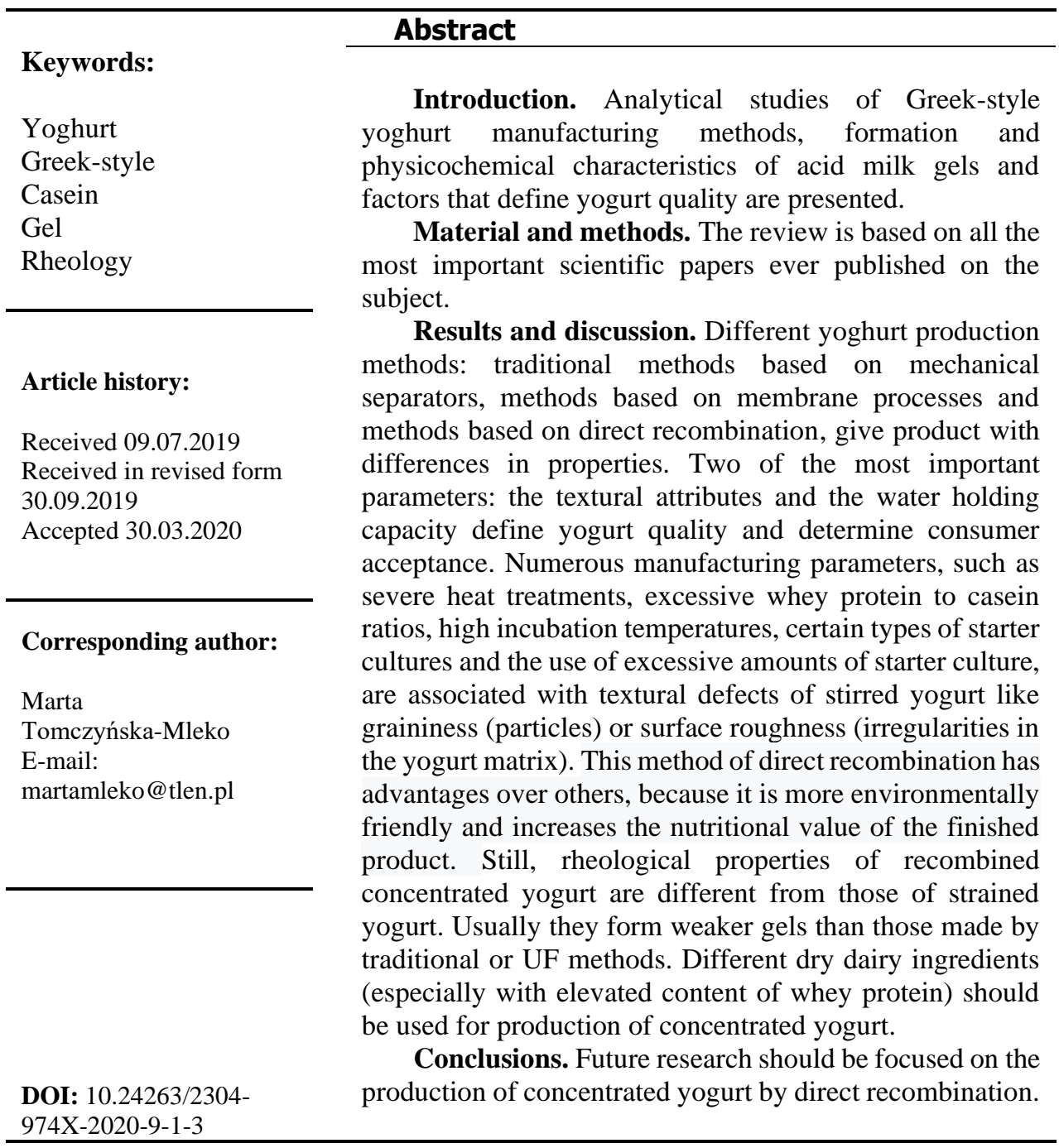




\section{Review structure}

1. Introduction

2. General technology of yogurt manufacturing

2.1. Milk standardization

2.2. Homogenization

2.3. Heat treatment

2.4. Incubation/fermentation

2.5. Cooling and storage

3. Greek-style yogurt manufacturing methods

3.1. Traditional method

3.2. Methods based on mechanical separators

3.3. Methods based on membrane processes

3.4. Methods based on direct recombination

4. Formation and physicochemical characteristics of acid milk gels

4.1. Casein micelle structure

4.2. Formation of acid milk gels

4.3. Effects of heat treatment on the formation of acid milk gels

5. Important factors that define yogurt quality

5.1. Rheology

5.2. Whey separation

5.3. Clusters formation

\section{Conclusions}

\section{Introduction}

Yogurt is defined as the "food produced by culturing one or more of the optional dairy ingredients [cream, milk, partially skimmed milk or skimmed milk] with a characterizing bacterial culture that contains the lactic acid-producing bacteria, Lactobacillus bulgaricusand Streptococcus thermophilus" [1]. Yogurts differ according to their chemical composition, method of production, flavour used and the nature of post-incubation processing [2]. There are substantial differences in composition of Greek-style yoghurts measured in products in different countries. The carbohydrate, fat and protein contents ranged between 1-12, 0-20 and $3.3-11 \mathrm{~g} / 100 \mathrm{~g}$, respectively [3].

Greek-style yogurt, also known as strained yogurt, concentrated yogurt or thick yogurt, is a semisolid fermented milk product derived from yogurt by draining away part of its whey. As a result of this draining action, the final product has higher total solids and lower lactose contents than regular yogurt (Table 1).

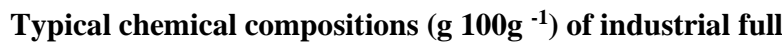

Table 1 and low-fat strained yogurt

\begin{tabular}{|c|c|c|}
\hline Composition & Full-fat & Low-fat \\
\hline Total solids & 22.0 & 14.3 \\
\hline Protein & 4.9 & 9.9 \\
\hline Fat & 10.1 & 0.2 \\
\hline Carbohydrate & 6.0 & 3.5 \\
\hline Ash & 1.0 & 0.6 \\
\hline
\end{tabular}

Source: Tamime (2003) [61]. 
The product has a cream/white color, a soft and smooth body, good spreadability with little syneresis and a flavor that is clean and slightly acidic [4]. Concentrated yogurt is widely consumed in the Middle East and Balkan regions [5, 6]. Evidence of its production can be found in many countries in Turkestan, the Balkans, the eastern Mediterranean, and the Indian subcontinent [7]. Table 2 shows the variety of names by which this product is known in different countries.

Table 2

Synonyms for concentrated yogurt in different countries

\begin{tabular}{|l|l|}
\hline \multicolumn{1}{|c|}{ Traditional names } & \multicolumn{1}{c|}{ Countries/Regions } \\
\hline Labneh, labaneh, lebneh, labna & Eastern Mediterranean \\
\hline Ta, than & Armenia \\
\hline Laban zeer & Egypt, Sudan \\
\hline Stragisto, sakoulas, tzatziki & Greece \\
\hline Torba, suzme & Turkey \\
\hline Syuzma & Russia \\
\hline Mastou, mast & Iraq, Iran \\
\hline Basa, zimne, kiselo, mleko-slano & Yugoslavia, Bulgaria \\
\hline Ititu & Ethiopia \\
\hline Greek-style & United Kingdom \\
\hline Chakka, shrikhand & India \\
\hline Ymer & Denmark \\
\hline Skyr & Iceland \\
\hline
\end{tabular}

Source: Tamime\& Robinson (2007a) [7].

Strained yogurt has a higher lactic acid concentration than normal yogurt $(1.8-2.0 \%$ as lactic acid). As a result, it presents a better keeping quality than the latter form [8-10]. High lactic acid concentrations can be expected to curtail the growth of bacterial pathogens, but yeasts, moulds and some lactic acid bacteria can still contribute to spoilage problems. At 7 ${ }^{\circ} \mathrm{C}$, concentrated yogurt can be kept for two weeks [4]. Any sharp taste resulting from the high lactic acid concentration will be masked by diacetyl produced during fermentation; and by the high fat content, which is typically around $10 \%$, and $[5,9]$.Furthermore, concentrated yogurt has superior nutritional properties to those of regular yogurt: it has higher protein $[2.5 \mathrm{x}]$ and mineral $[1.5 \mathrm{x}]$ concentrations; a higher number of viable lactic acid bacteria [there is a tendency for these bacteria to be retained in the crud during the concentration process]; a very low lactose concentration, which makes strained yogurt even more suitable for lactose intolerant individuals than regular yogurt; and a fat content which can be varied according to consumer demand [4, 11-14]. The perceived nutritional benefits and storage characteristics of Greek-style yogurt led to its increasing popularity and economic importance during the last decade of the past century [15-17]. Nowadays, concentrated yogurt is establishing as a popular nutritious product possessing a healthy image equal to or greater than that of regular yogurt $[4,6]$. The CODEX ALIMENTARIUS classifies strained yogurt as a type of concentrated fermented milk and its composition and quality standards are described in: CODEX STAN 243-2003 [18]. Yogurt, essentially from the Eastern hemisphere, has gained considerable popularity as a wholesome and nutritious food in America. Indeed, its health properties, which extend beyond nutrition, are now being recognized [19, 20]. Reported health benefits associated with yogurt and probiotic cultures include growth promotion, enhancement of mineral absorption, lactose digestion (the ability to reduce symptoms of 
lactose intolerance), antimicrobial function (the ability to enhance resistance to colonization by pathogenic organisms), anticholesterol effect (the ability to reduce the risk of cardiovascular disease by lowering serum cholesterol), anticarcinogenic factor (the ability to reduce risk factors for colon cancer initiation), stimulation of the host immunological system, restoration of normal balance of gastrointestinal microflora, and positive contribution to longevity [19, 21-26]. Consumption of yoghurt, despite the relatively high content of saturated fat, has been lately linked with lower blood pressure, but the mechanism is unclear [27]. Added to this, yogurt is commonly supplemented with various functional ingredients, such as probiotics, prebiotics, fiber, plant sterol esters, omega-3 fatty acids, minerals and vitamins to impart an even healthier image to the final product [19]. The developments of new products, along with increased consumer awareness of the health benefits associated with yogurt cultures and probiotics, had led to a sharp increase in the per capita consumption of yogurt in Canada and the U.S. during the last decades. According to the Canadian Dairy Information Centre, Canadians consumed 9.87 liters (per capita) of yogurt in their diet in 2018, almost twice as much as they had two decades ago [28]. The introduction of Greek yogurt changed American tastes in yogurt, which helped increase sales of the overall yogurt category. As of 2016, the Americas held a share of over 50 percent of the global Greek yogurt market. In contrast to conventional yogurt, the Greek type is bought equally by men and women and consumers are drawn to the creamy texture and its high protein content. The Greek yogurt category experienced tremendous growth in the United States over the past few years. Americans consumed 13.7 liters (per capita) of yogurt in their diet in 2017 with 37.8\% of Greek-type share [29].

\section{General technology of yogurt manufacturing}

At present, there is a wide variety of yogurt types on the market $[24,30]$. Yogurts are usually classified based on their fat content (full-fat, reduced-fat, and low-fat) and on the method of production and the physical structure of the coagulum (set or stirred yogurts). Set yogurt is the product formed when the fermentation of milk is carried out in a retail container, and the yogurt produced is in a continuous semisolid mass. In contrast, stirred yogurt results when the coagulum is produced from milk, and the gel structure is broken before cooling and packaging. Fluid yogurt can be considered as stirred yogurt of low viscosity [2]. The main processing steps involved in these two types of yogurt manufacturing (Figure 1) include the standardization of milk (fat and protein content), homogenization, milk heat treatment, incubation/fermentation, cooling, and storage [31].

\subsection{Milk standardization}

Nowadays, three systems are available to standardize the fat and protein content of the milk base: (1) the addition of milk powders to liquid milk, (2) the evaporation of water from liquid milk under vacuum, (3) the removal of water from liquid milk by membrane processes [9]. Milk bases should be formulated to comply with regulations and meet consumer expectations [32]. Stabilizers (gelatin, starch, pectin) and sweeteners can also be added to further impact the physical properties of the final product [33]. Increasing the total solids increases the firmness, complex viscosity, storage modulus, fracture stress, apparent viscosity, oral viscosity, consistency index, and water holding capacity - WHC of the resultant gel [31,34-46]. Thus, it improves the textural attributes of the gel, giving a higher sensory acceptability to the final product [12, 47-49]. 


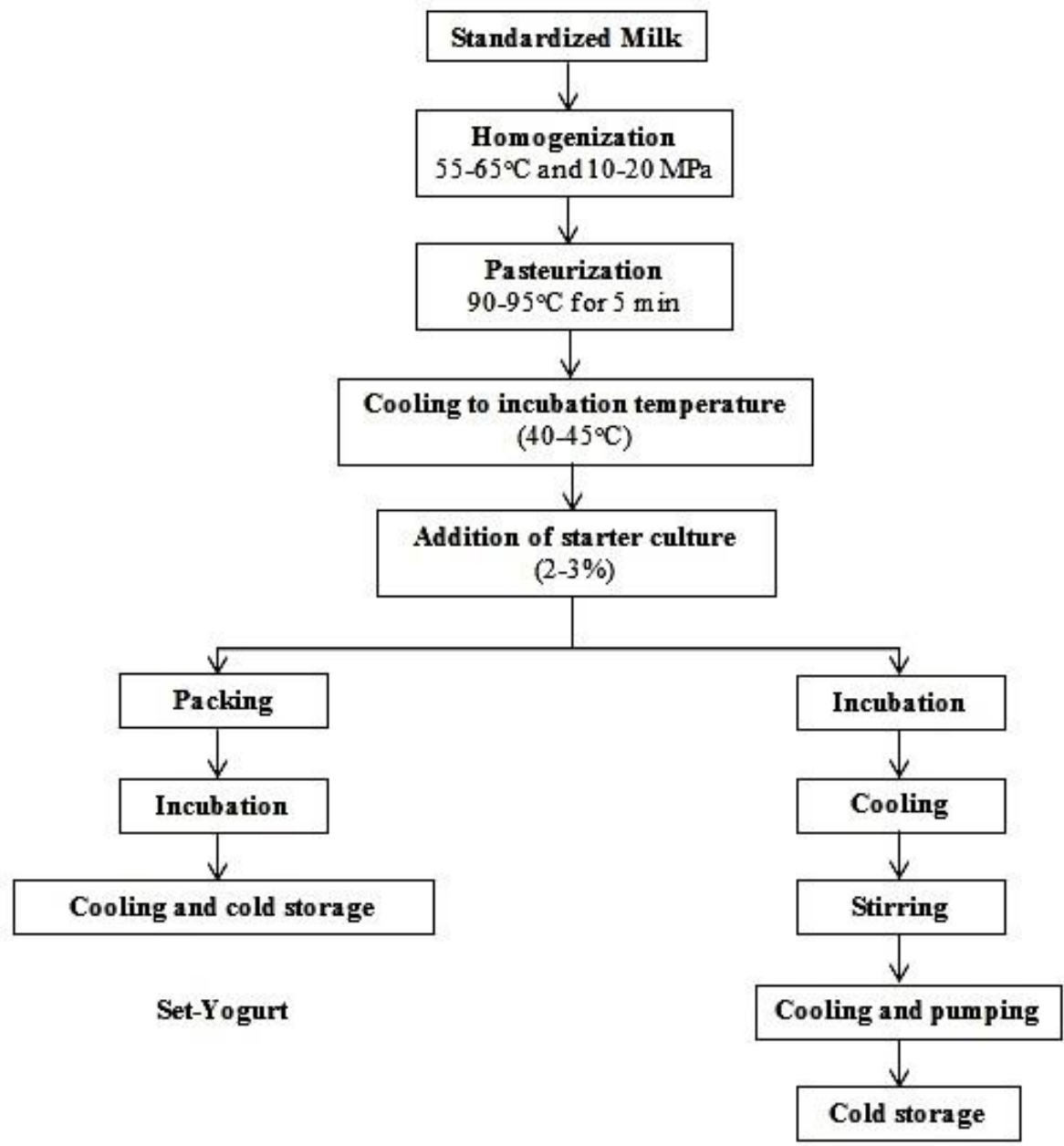

Stirred-Yogurt

Figure 1. Main processing steps in the manufacture of set and stirred yogurt Source: Adapted fromLee \& Lucey (2010) [31].

\subsection{Homogenization}

Homogenization is the typical industrial process used to effect stabilization of the lipid phase against separation by gravity. During this process the average diameter of fat globules $(3-4 \mu \mathrm{m})$ is reduced to 1 or $2 \mu \mathrm{m}$. As a result, the fat globules do not cream during the incubation of the yogurt. Because of the size reduction, there is usually a four-to-six-fold increase in the surface area [2]. Upon homogenization, the fat-globule membrane is destroyed, and caseins and whey proteins form the new surface layer of fat globules, which increases the number of possible structure-building components in yogurt made from homogenized milk. Homogenized milk fat globules act like protein particles due to the 
presence of protein on the fat surface [31]. Therefore, homogenization also improves gel strength upon fermentation due to greater protein-protein interaction [24]. As the fat globule membrane is destroyed during homogenization, lipids are vulnerable to attack by lipase. To prevent lipolysis, milk must be pasteurized immediately after homogenization [2]. Homogenization pressures used are usually between 10 and $20 \mathrm{MPa}$ and, since the efficiency of homogenization is much better when the fat phase is in a liquid state, the process is usually carried out at high temperatures $\left(55^{\circ} \mathrm{C}\right.$ to $\left.80^{\circ} \mathrm{C}\right)$ [33].

\subsection{Heat treatment}

Heat treatments, which are much more severe than fluid milk pasteurization, are necessary to:

1. Generate a yogurt with the desired textural properties. Thus, the heating/holding regime both alters the physicochemical properties of the caseins and denatures the whey proteins, so that $\beta$-lactoglobulin, in particular, may become attached to the casein micelles; this linkage improves the texture (set yogurt) or viscosity (stirred yogurt) of the final product.

2. Cause some breakdown of the whey proteins to liberate free amino acids that stimulate the activity of the starter culture.

3. Expel oxygen from the processed milk because, as the starter bacteria are microaerophilic, deaeration provides the correct environment for rapid growth.

4. Kill any non-sporing pathogens that may be present, helping to ensure that yogurt retains its image as a "safe" product [9].

To meet these requirements, milk is generally heated, using a continuous plate heat exchanger, at 85 to $95^{\circ} \mathrm{C}$ for 10 to 30 minutes [30]. According to Chandan and O'Rell [33], optimum results are obtained by using a heat treatment of $90-95^{\circ} \mathrm{C}$ and a holding time of 510 minutes.

\subsection{Incubation/fermentation}

After heat treatment, the milk base is cooled to the incubation temperature used for growth of the starter culture.An optimum temperature of the thermophilic lactic acid bacteria, i.e., Streptococcus ssp. thermophilus and Lactobacillus delbrueckii ssp. bulgaricus, is around $40-45^{\circ} \mathrm{C}$. Bacterial fermentation converts lactose into lactic acid, which reduces the $\mathrm{pH}$ of milk. During the acidification of milk, the $\mathrm{pH}$ decreases from 6.7 to $\leq 4.6$. In unheated milk gels, gelation occurs at around $\mathrm{pH} 4.9$, while in heated milks gelation occurs at $\mathrm{pH} 5.2-5.4$ (because denatured $\beta$-lactoglobulin has a higher isoelectric point than casein) $[31,50,51]$.

The essential flora of yogurt (Sc. thermophilus and Lb. delbrueckiissp. bulgaricus) displays an obligate symbiotic relationship during their growth in a milk medium. The rates of acid and flavor production by mixed yogurt cultures are considerably higher than by either of the two organisms grown separately [33, 41]. Lb. delbrueckiissp. bulgaricus hydrolyzes milk proteins, the caseins, thus releasing essential amino acids, including valine, which stimulate the growth of $S c$. thermophilus. Initially, Sc. thermophilus grows rapidly, reducing the $\mathrm{pH}$ to around 5.4, which stimulates the growth of Lb. delbrueckii ssp. bulgaricus, which is acid-tolerant and produces large amounts of lactic acid, which reduces the pH.Sc. thermophilus uses oxygen during its growth, which makes oxidation-reduction potential more favorable for $L b$. delbrueckii ssp. bulgaricus; it also produces purine, pyrimidine, $\mathrm{CO}_{2}$, formic acid, oxaloacetic acid, and fumaric acid that stimulate the growth of the lactobacillus $[2,33,41]$. During the growth in milk, L. delbrueckiissp. bulgaricusapparently exhibits a 
preference for utilizing $\beta$-casein over other proteins as a nitrogen source, indicating that the type of protein is also an important factor influencing the growth of this culture [41].

Starter bacteria can continue to produce acid until a very low $\mathrm{pH}$ [e.g. 4.0] is attained when bacteria become inhibited by the low $\mathrm{pH}$; in practice bacterial gels are cooled when sufficient acidity has been attained $[\mathrm{pH} \sim 4.6]$. The rate of $\mathrm{pH}$ change during fermentation or addition of acid is controlled by the acid-base buffering properties of milk [38].

\subsection{Cooling and storage}

Since the yogurt organisms show limited growth activity around $10{ }^{\circ} \mathrm{C}$, the primary objective of cooling is to drop the temperature of the coagulum from $30-45^{\circ} \mathrm{C}$ to $<10{ }^{\circ} \mathrm{C}$ as quickly as possible so as to control the final acidity of the product. The process of cooling yogurt may be carried out using one-phase or two-phase cooling [52]. In single-phase cooling, the temperature of fermenting milk is directly reduced from $43{ }^{\circ} \mathrm{C}$ to $<10{ }^{\circ} \mathrm{C}$. This model is more appropriate for plain set-type yogurt production. Two-phase cooling is widely employed for stirred-type yogurt production. In the first phase, fermenting milk is stirred gently in a tank to obtain a homogeneous body, and cooled to $20-24{ }^{\circ} \mathrm{C}$. At this stage, fruit is added and the yogurt cups are filled. The filled cups are then cooled to $<10{ }^{\circ} \mathrm{C}$ over a period of 10-12 hours [41]. To improve yogurt quality, the second stage of cooling should be carried out as slowly as possible over a 12-hour period [2]. The rate of cooling is of critical importance in obtaining a product with the desired textural quality. Cooling too quickly can cause a weak body and stimulate whey separation during cold storage [41]. Storing yogurt for 1-2 days improves the viscosity. During the first 24-48 hours of cold storage, an improvement in the physical characteristics of the coagulum is observed, mainly because of hydration and/or stabilization of casein micelles. Proper hydration is required to avoid syneresis. It is therefore important to delay the sale or distribution of yogurt for $24-48$ hours [2].

\section{Greek-style yogurt manufacturing methods}

Much of the concentrated yogurt consumer acceptability is dependent on its sensory properties, which in turn, seem to be heavily dependent on the method of processing of the material $[14,16,53,54]$. Depending on the used process, Greek-style yoghurt can be 10 times better than traditional yoghurt to deliver probiotic bacteria. Fresh ultrafiltrated or centrifugated Greek-style yoghurts had between 3 and 7 times higher counts of Lb. helveticus and $S$. thermophilus than the regular stirred yoghurt [55]. Concentrated yogurt is traditionally manufactured by straining the natural set yogurt in cloth bags [56]. However, nowadays there are other methods available to manufacture this product in large volumes. The current methods available for manufacturing concentrated yogurt have been widely reviewed by Tamime and Robinson [7, 8, 57], Robinson and Tamime [58], Özer [59], Salji [21], Nsabimana et al. [4], Tamime [60, 61], Tamime and Marshall [62], Tamime et al. [63] and can be classified as follows:

1. Traditional method (cloth bag) [10, 53, 64-73].

2. Methods based on mechanical separators [74-76].

3. Methods based on membrane processes [10, 53, 64-71, 77-81].

4. Methods based on direct recombination [53, 67-70, 82, 83]. 


\subsection{Traditional method}

The basic principle of using the traditional cloth bag method is to extract water from plain yogurt until the desired total solids level has been reached. The duration of drainage for yogurt in cloth bags takes about $15-20$ hours at $<10^{\circ} \mathrm{C}$. The whey separation can be achieved either by gravity drainage (small scale production) or by pressing (large scale production, i.e., by piling $25-\mathrm{kg}$ bags on top of each other); however, the drainage time can be shortened by up to 6 hours by applying pressure of $2 \mathrm{~kg} \mathrm{~kg}^{-1}$ on the yogurt [59].

The sensory properties of the product made with this traditional system are excellent [9]. However, this method could be described as slow, labour intensive and unhygienic by the nature of the process, and the yield obtain is rather low due to residues left in the bag [9, $10,64,82,84]$. Consequently, this system is not suitable for large-scale processing [21, 53]. Despite this, the traditional production method is still preferred in some countries in the Middle East, as the investment in mechanised systems of production is rather high [59].

\subsection{Methods based on mechanical separators}

Mechanical separators have been used successfully for the industrial-scale production of strained yogurt [62]. Salji et al. [11, 85] reported the use of this method for factory-scale production in Saudi Arabia. This method requires the use of a nozzle or Quarg separator. Only, skimmed milk should be used when manufacturing yogurt in this way; if whole milk is used, the fat globules will clog the separator nozzles. However, recent developments in the design of centrifugal separators have made it feasible to use fermented whole milk to produce strained yogurt [61]. Producing concentrated yogurt by centrifugation is a two-step procedure. First, milk is fermented until it achieves the desired level of acidification $(\mathrm{pH}$ 4.64.8). After acidification, fermented skimmed milk is stirred vigorously, heated up to 55-60 ${ }^{\circ} \mathrm{C}$ to inactivate the culture and control the level of acidity, and cooled to $40{ }^{\circ} \mathrm{C}$. Next, any large clots or clumps are removed by passing the fermentate through a metal sieve before it enters the separator. The fermented milk is also de-aerated for 15-20 minutes before entering the centrifuge to assist the separation of whey in the separator. Once in the separator, the fermented milk is concentrated to the desired total solids level. The concentrated product leaving the separator is blended with any source of fat or cream, to provide the desired fat level in the final product. Then it is cooled and packaged [4, 7, 8, 59-61]. Capacities of such separators are up to 6.5 tonnes $\mathrm{h}^{-1}$, depending on the composition of the milk used and the acidity of the fermented milk prior to concentration [61, 62].According to Dagher and AliGhariebeh [74], strained yogurt, produced from heated yogurt by centrifugation for 5 minutes at different speeds between 4,000 and 11,700g, had organoleptic characteristics similar to those of control samples made by the traditional method.

\subsection{Methods based on membrane processes}

Membrane techniques, especially ultrafiltration (UF), have been successfully used in the yogurt industry for the last 20-25 years [59, 81]. Production of strained yogurt by reverse osmosis (RO) has also been studied. However, previous scientific works revealed that using RO to produce concentrated yogurt created weaker structures which did not give gel properties close to those of concentrated yogurt made by the traditional method [53, 67-70, 78]. Two different systems of UF have been used to produce concentrated yogurt: (a) the fermentation of UF retentate that has the solids content desired in the final product $[79,80$, $71]$, and (b) UF of yogurt at $40-50{ }^{\circ} \mathrm{C}[10,66,77]$ to produce a concentrated product with the desired total solids content [7]. Several scientific works studied the microstructures and rheological properties of concentrated yogurt obtained by these two UF methods [10, 64, 67- 
70, 78]. Greek yoghurts prepared by concentrating a milk base through UF to $13.8 \%$ exhibited a hard structure, low syneresis and a high protein and fat content [86]. Applying both, UF and straining, resulted yoghurts with required structural attributes while substantially reducing the generation of AW. Researchers concluded that the concentrated yogurt made from UF milk retentate had much greater firmness than the products manufactured using the traditional method or UF of yogurt $[4,7,10,61,64]$. The concentration of milk by UF before yogurt-making carries a risk of bitterness in the final product since the calcium content will be higher [59]. On the other hand, the quality of strained yogurt made by UF of warm yogurt closely resembles the traditional product in terms of elasticity, firmness, and structure [10, 61]. Unfortunately, UF of yogurt affects process efficiency due to permanent membrane fouling [81]. The manufacturing process is as follows: after the fermentation period, the warm yogurt is heated to $58-60^{\circ} \mathrm{C}$ for 3 minutes in the plate heater exchanger, to inactivate the culture and control the level of acidity, cooled to $40{ }^{\circ} \mathrm{C}$, concentrated in a two-to-four stage UF plant (depending on the desired degree of concentration), cooled in a plate cooler to about $20^{\circ} \mathrm{C}$ and finally packaged [4]. According to Özer et al. [53] and Tamime et al. [10, 64], UF applications can be used as an industrial alternative to the traditional strained yogurt-making process. Several studies which have investigated the rheology of concentrated yogurt produced by a range of techniques for increasing total solids have concluded that compared to other techniques (such as RO and direct recombination), UF of yogurt gives the gel properties that are closest to those of the traditional product $[53,67,78]$. Other advantages of UF as compared with other conventional methods are: higher yield (10\% increase), shortening of processing time (e.g., by $25 \%$ ), reduced wheying-off, and easy automation and process control [4, 59]. In addition, when using UF instead of the traditional method, the volumes of milk and starter cultures are reduced by around $10 \%$ and $80 \%$, respectively [59]. Due to all these advantages, a wide range of UF plants are now available on the market for the production of strained yogurt on a large scale $[58,60,61]$.

\subsection{Methods based on direct recombination}

According to the Food and Agriculture Organization of the United Nations, a recombined milk product is a product resulting from the combining of milk-fat andmilksolids-non-fat in their preserved forms with or without the addition of water toachieve the appropriate milk product composition [87]. In order to eliminate the drainage stage during the manufacture of concentrated yogurt, it is feasible to manufacture this product from recombined dairy ingredients [59-61]. The process involves reconstituting powders in water, up to the total solids level required in the final product, and blending the reconstituted milk with anhydrous milk fat and stabilisers [61]. After the recombination is complete, the recombined milk is handled and processed in a similar way to the production of traditional yogurt [8]. The quality of recombined dairy products is directly related to the composition, properties, and microbiological standards of the ingredients used [83]. According to Gilles and Lawrence [82], good quality yogurt can be obtained from milk powders as long as the powders are free of off-flavours. Odet [88]] stated that there were no organoleptic differences between yogurt produced from recombined and fresh milks. The introduction of membrane techniques to the dairy industry has enabled the production of different types of milk powders containing diverse protein to lactose ratios and altered whey protein to casein ratios (e.g., milk retentate, milk permeate, whey retentate, and whey permeate powders) $[89,90]$. The use of these latter powders has enabled the production of recombined dairy products containing high protein and low lactose contents, such as concentrated yogurt [14]. Several authors recommended using these types of powders to fortify the milk base during yogurt 
production and/or to produce concentrated yogurt using recombination technology [36, 61, 82, 91-93]. In order to obtain a recombined strained yogurt with good textural and physicochemical properties, experts recommend using heat-treated high protein dairy powders (with reduced lactose content) free of inhibitory substances that can slow or restrain the growth of lactic bacteria $[82,94,95]$. However, if processing steps include a high heat treatment, low-heated milk powders can also be used effectively to produce a good quality product [95]. Since recombined products generally contain high amounts of water, it is important to have a high quality water source. Excessively hard water can lead to problems with powder solubility and stability [95]. According to the recommendations from the International Dairy Federation (IDF), water used to recombine dairy products should not exceed the following maximum salt concentrations: total hardness, $100 \mu \mathrm{g}$ of calcium carbonate $\mathrm{g}^{-1}$; chloride, $100 \mu \mathrm{g} \mathrm{g}^{-1}$; sulfate, $100 \mu \mathrm{g} \mathrm{g}^{-1}$; nitrate, $45 \mu \mathrm{g} \mathrm{g}^{-1}$ [96]. Nichols and Kozak [97] discussed in depth the importance of water used for recombining milk and milk products. Milk powders used for recombination are very stable and have a shelf-life of 12 months at ambient temperatures without refrigeration, although storage at $20^{\circ} \mathrm{C}$ or below is recommended [98]. The long durability and good thermal stability of ingredients makes direct recombination a suitable option to provide a nutritious and high-quality source of dairy products in areas where a fresh raw milk supply is not readily available or is in short supply [17]. Because refrigeration and transportation may not be readily available in some regions, utilization of preserved milk ingredients may be the only viable means of producing dairy products [95]. Several authors [99-103] reported the use of recombination technology to produce milk and dairy products in developing countries where, as a result of geographic/climatic/economic conditions, setting up a conventional dairy industry base using local milk production is impractical [104]. On the other hand, in industrialized countries where there is a milk surplus, milk recombination offers the opportunity to transfer raw materials (milk powders, anhydrous milk fat, etc.) from surplus production areas to deficiency areas, in order to compensate for the abovementioned problems and to open up new markets $[14,96]$. Therefore, it is believed that a widespread use of this technique to produce concentrated yogurt will potentially increase the international trade of powders high in protein and low in lactose $[14,89]$. However, it is important to point out that indiscriminate distribution of dairy ingredients for recombining purposes can, under certain circumstances, be detrimental to local milk producers [104]. The production of concentrated yogurt by direct recombination offers important advantages over other industrial production methods. Direct recombination does not involve whey disposal problems (there is less environmental damage, and the yogurt produced is more nutritious because all whey proteins are retained in the final product) and requires low investment and production costs (depending on the local market) $[89,98]$. However, several scientific publications stated that the rheological properties of recombined concentrated yogurt were different from those of strained yogurt produced by the traditional method or by UF [7, 8]. Özer et al. [53, 67, 69, 70] concluded that strained yogurt made by directly recombining full-cream milk powder to $23 \%(\mathrm{w} / \mathrm{v})$ total solids formed weaker gels than those made by traditional or UF methods. Although numerous scientists have studied or reviewed the production of recombined concentrated yogurt $[7,8$, $53,59-61,67-70,82,83,95]$, there is little evidence of the manufacture of recombined nonfat strained yogurt. In the future it is crucial to find an effective formulation for producing a recombined non-fat, additive-free type of Greek-style yogurt. 


\section{Formation and physicochemical characteristics of acid milk gels}

Acid-induced milk gels are formed by aggregation of casein particles as the $\mathrm{pH}$ of milk decreases and the isoelectric point ( $\mathrm{pH}$ 4.6) of casein is approached [105]. Acid casein gels have a particulate, heterogeneous structure, consisting of fairly large conglomerates and holes (void spaces where the aqueous phase is confined). These conglomerates are thought to be built of smaller ones, which, in turn, consist of casein particles aggregated in strands and nodes. This heterogeneity, which depends, e.g., on the temperature during gel formation, largely determines the mechanical properties of the gel $[38,106]$. Casein gels are very dynamic and rearrangements of the clusters and particles forming the network may occur before or during gel formation [105]. The physical characteristics of these particulate gels are determined by both strong permanent bonds (covalent bonds: SH/S-S exchange) formed during the aggregation, and subsequent rearrangements of protein particles (noncovalent bonds: electrostatic, hydrophobic interactions and, probably, the ever-present Van der Waals attraction, as well as steric and entropic effects related to protein conformation). The balance between these strong and weak bonds controls the rheology of yogurt gels $[53,70,106]$. Milk protein gels are irreversible, in contrast to many other food gels. Although milk gels are usually classified as particle gels, it is now recognized that they are not simple particle gels because the internal structure of the casein particle plays an important role in the rheological properties of milk gels [37].

\subsection{Casein micelle structure}

At least three types of models for the structure of casein micelles have been proposed. Schmidt [107] and Walstra [108] suggested a model that proposes that the micelle core is divided into discrete sub-units [sub-micelles] with distinctly different properties [37]. In this model, the individual caseins come together in their appropriate portions to form internal sub-micelles, if depleted in $\kappa$-casein, or external sub-units rich in $\kappa$-casein, colloidal calcium phosphate (CCP) is regarded as the cement which links these discrete sub-units together. Another model, proposed by Holt [109], regards the micelle as a mineralized, cross-linked protein gel in which the CCP nanoclusters are the agents responsible for cross-linking the proteins and holding the network together [110]. A major failing of these two models is their lack of a plausible mechanism for assembly, growth and, more importantly, termination of growth of the casein micelles. All such elements are in place in a recent model, proposed by Horne [110], which suggests a dual-binding (polycondensation-type) mechanism for gel assembly [37, 111]. In the dual-binding model, micellar assembly and growth take place by a polymerization process involving, as the name suggests, two distinct forms of bonding: crosslinking through hydrophobic regions of the caseins or bridging across CCP nanoclusters. Central to the model is the concept that micellar integrity and hence stability is maintained by a localized excess of hydrophobic attraction over electrostatic repulsion [111]. The energy of interaction between molecules present inside the micelle is calculated as the sum of electrostatic repulsion and hydrophobic attraction as

$$
I E=E R+H I
$$

where, IE: interaction energy; ER: electrostatic repulsion; HI: hydrophobic interaction [110]. This model sees the micellar CCP not just as cross-links but also as neutralizing agents which, being positively charged, bind to negatively charged phosphoserine clusters to reduce the protein charge to the level where the attractive interactions between the hydrophobic regions of the caseins can be allowed to dominate [110]. Figure 2 illustrates the structure of the casein micelle according to the dual-binding model and can be used to explain the two types of linkage postulated between protein molecules. The first linkage is hydrophobic, where two or more hydrophobic regions from different molecules form a bonded cluster. 

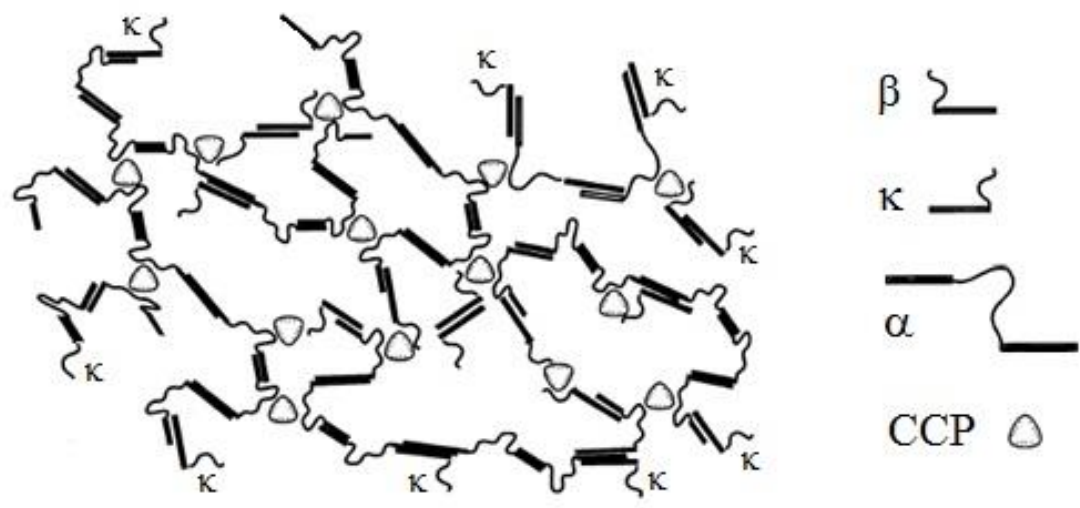

Figure 2. Dual-binding model of structure of casein micelle

Bonding occurs between the hydrophobic regions, shown as rectangular bars, and by linkage of hydrophilic regions containing phosphoserine clusters to CCP clusters. Molecules of $\kappa$-casein limit

further growth and are labeled with the letter ' $\kappa$ '. Source: Adapted from Horne (1998) [110].

The growth of these polymers is inhibited by the protein-charged residues whose repulsion pushes up the interaction free energy. Neutralization of the phosphoserine clusters by incorporation into the CCP diminishes that free energy as well as producing the second type of cross-linking bridge, since it is considered that up to four or more phosphoserine clusters from different casein molecules can be accommodated at each CCP nanocluster [Horne, 1998] [110]. Although the $\kappa$-casein molecules can interact via their hydrophobic domains with the hydrophobic regions of the other caseins, further growth beyond the $\kappa$ casein is not possible because it possesses neither a phosphoserine cluster for linkage via $\mathrm{CCP}$ [the only phosphoserine residue in $\kappa$-casein lies in the macropeptide which forms the putative hairy layer deemed essential for micellar stability in all accepted models, thus, this residue cannot be involved in any cross-linking via $\mathrm{CCP}]$, nor another hydrophobic anchor point to extend the chain via this route. $\kappa$-Casein acts as a terminator for both types of growth. Unless circumvented by the growing network, it will become part of the surface structure of the micelle. Hence its surface location, a prime requirement for any structural model, arises naturally in this model [110]. This concept of a localized excess of hydrophobic attraction over electrostatic repulsion allows the visualization of micellar growth and successfully accommodates the response of the micelles to changes in $\mathrm{pH}$, temperature, urea addition or removal of CCP by sequestrants, all in accordance with experimental observations [112]. Urea does not rupture the CCP linkages but disrupts the hydrophobic bonds, bringing about micellar disintegration. Further, micellar integrity is largely maintained when the CCP is dissolved out by acidification because the phosphoserine negative charges are neutralized by the acid medium. If the milk is dialyzed and the $\mathrm{pH}$ is then restored to that of the original milk, dissociation of the micelle complex is observed as the negative charges of the phosphoserine residues are not neutralized and the electrostatic repulsion effect predominates over the hydrophobic attraction. The same dissociation is observed at natural $\mathrm{pH}$ when the $\mathrm{CCP}$ is removed by sequestration with EDTA. Increasing $\mathrm{pH}$ from the natural value in milk leads to dissociation of the micelles. Whether this is due to conversion of the phosphoserine residues from singly to doubly negatively charged units which are no longer capable of linking to the CCP nanoclusters, or whether the increase in charge itself is sufficient to upset the balance of electrostatic repulsion and hydrophobic attraction in favour of electrostatic 
repulsion and the micelles dissociate. Decreasing the temperature decreases the level of hydrophobic attraction and any $\beta$-casein not linked through its phosphoserine cluster could then be released into the serum phase [110-112]. These facts suggests that CCP does not cement the micelle together, as described by the earlier models, but rather it helps to control and modulate the effects of calcium and charged groups on caseins. It is also clear that hydrophobic interactions and hydrogen bonding are important for micelle integrity [37].

\subsection{Formation of acid milk gels}

As the $\mathrm{pH}$ of milk is reduced, CCP is dissolved, the micelle structure is altered (the charge on individual caseins is altered and the ionic strength of the solution increased) and caseins are liberated into the serum phase $[38,113]$. The extent of liberation of caseins depends on the temperature at acidification (low temperatures results in a decrease in the level of hydrophobic attractions inside the casein micelle); at fermentation temperatures commonly used for yogurt manufacture $\left(>30^{\circ} \mathrm{C}\right)$, no dissociation of casein likely occurs [113]. When the isoelectric point of caseins $(\mathrm{pH} \approx 4.6)$ is approached, aggregation occurs and low-energy bonds, mainly hydrophobic, are progressively established between proteins [114]. Three $\mathrm{pH}$ regions in the acidification of milk from $\mathrm{pH} 6.7$ to 4.6 can be distinguished:

a. $p H$ from 6.7 to 6 . The decrease in $\mathrm{pH}$ causes a decrease in the net negative charge on the casein micelles, thereby reducing electrostatic repulsion. Only a relatively small amount of CCP is dissolved above $\mathrm{pH} 6.0$, so the structural features of the micelles are relatively unchanged (e.g., size) [115].

b. $p H$ from 6 to 5 . As the $\mathrm{pH}$ of milk decreases further from $\mathrm{pH} 6.0$ to 5.0, the net negative charge on casein micelles greatly decreases and the charged "hairs" of $\kappa$-casein may shrink (or curl up). This results in a decrease in electrostatic repulsion and steric stabilization, which are both responsible for the stability of casein micelles in the original milk. At $\mathrm{pH} \leq 6.0$ the rate of solubilization of $\mathrm{CCP}$ increases, which weakens the internal structure of casein micelles and increases the electrostatic repulsion between the exposed phosphoserine residues. In milk, CCP is completely solubilized in casein micelles by $\mathrm{pH} \sim 5.0$ [31].

c. $p H \leq 5$. When the $\mathrm{pH}$ of milk becomes close to the isoelectric point of casein $(\mathrm{pH}$ 4.6), there is a decrease in the net negative charge on casein, which leads to a decrease in electrostatic repulsion between casein molecules. On the other hand, casein-casein attractions increase due to increased hydrophobic and electrostatic charge interactions (and van der Waals' forces) [31, 50]. In unheated milk, gels gelation occurs at around $\mathrm{pH} 4.9$, while in heated milks, gelation occurs at $\mathrm{pH}$ 5.2-5.4 (because denatured $\beta$-lactoglobulin has a higher isoelectric point than casein) $[31,50,51]$. Casein particles aggregate as a result of (mainly) charge neutralization [50]. The acidification process results in the formation of a three-dimensional network consisting of clusters and chains of caseins [31].

Solubilization of CCP during the acidification process undoubtedly changes the structural integrity of the casein micelles [48]. When CCP is depleted from the micelle, the casein molecules will have more dispersed structures with a higher number of interaction sites [112]. Therefore, the loss of CCP from casein micelles dramatically influences the properties of casein gels [115]. If the acidification is proceeding slowly, then this may allow equilibration and rearrangement into localized denser structures with few linkages between, giving rise to weaker gels. More rapid drops in $\mathrm{pH}$ may lock the protein into a more dispersed structure with greater density of possibly stronger strands [112]. These statements are verified by the experimental work done by Lee and Lucey [116]. These authors reported that higher 
inoculation rates resulted in lower fermentation times and stiffer gel networks. They support their results by stating that the solubilization of CCP in milk during acidification is a slow process, and may require a slightly lower $\mathrm{pH}$ to completely dissolve $\mathrm{CCP}$ under conditions of fast acidification. When $\mathrm{CCP}$ dissolves at a lower $\mathrm{pH}$, caseins at this lower $\mathrm{pH}$ value may be less sensitive to excessive rearrangements (due to the fact that at lower $\mathrm{pH}$ values there will be lower electrostatic repulsion and higher hydrophobic interactions between casein particles); thus, stiffer gel networks are obtained. Consequently, the solubilization of CCP appears to alter the balance between viscous and elastic components in the gel network [37].Hydrophobic interactions are unlikely to play a direct role in the strength of acidgels as the stiffness of acid gels increases as the measurement temperature decreases. Cooling results in an increase in the stiffness of the gel, probably as a result of the swelling of casein particles (caused by the weaker hydrophobic interactions) and an increase in the contact area between particles. A similar trend occurs when lower incubation temperatures are used. The use of lower incubation temperatures leads to longer incubation times, but firmer and more viscous gels that are less prone to whey syneresis are formed. At a lower incubation temperature, there is an increase in the size of the casein particles because of a reduction in hydrophobic interactions which, in turn, leads to an increased contact area between the casein particles [50]. Higher incubation temperatures (i.e., higher gelation $\mathrm{pH}$ ) also make the gel network more prone to rearrangements during gelation, and these changes can lead to greater whey separation $[50,116]$.

\subsection{Effects of heat treatment on the formation of acid milk gels}

With the exception of proteose-peptone, whey proteins are very sensitive to heat treatment. Unlike caseins, whey proteins have three-dimensional structures or configurations. Each configuration is stabilized by hydrogen and hydrophobic bonds, and other forces. Secondary and tertiary structures of whey proteins tend to be broken down by heat treatment because heating weakens hydrogen and hydrophobic bonds [41]. Denaturation of whey proteins occur above $60{ }^{\circ} \mathrm{C}$. At temperatures up to $90{ }^{\circ} \mathrm{C}$, unfolding of the protein is ratelimiting but further increases in the heating temperature result in only small increases in the rate of denaturation as aggregation of the proteins becomes rate-limiting [117]. Below $65^{\circ} \mathrm{C}$, at least in theory, denaturation or functional changes of whey proteins (mainly $\beta$ lactoglobulin) are reversible, but above $70{ }^{\circ} \mathrm{C}$ irreversible functional changes in whey proteins occur [41]. The most abundant whey protein is $\beta$-lactoglobulin in which a heatinduced conformational change results in the exposure of a reactive thiol group (Figure 3).
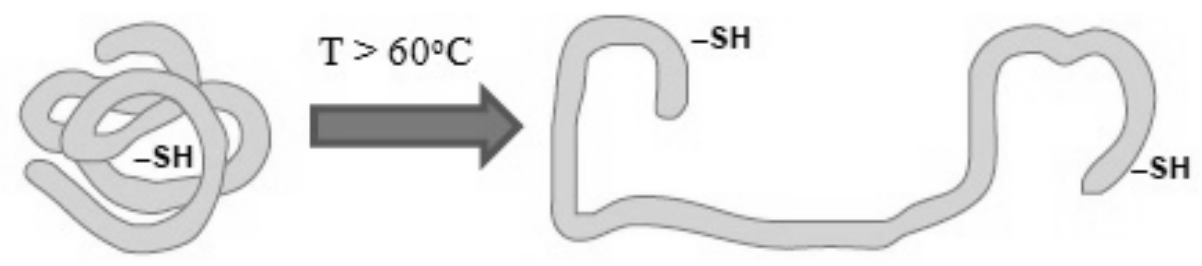

Figure 3. Schematic representation of $\beta$-lactoglobulin denaturation: breakage of its tertiary structure and exposure of thiol groups

Source: Adapted from Bylund (1995) [136]. 
This thiol group can form disulfide bonds with other cysteine-containing proteins, such as $\beta$-lactoglobulin or bovine serum albumin, or with proteins having disulfide bridges, such as $\alpha$-lactalbumin, $\kappa$ - and $\alpha_{2}$-casein. The latter process occurs through thiol group-disulfide bridge exchange reactions, resembling a polymerization process in which heat-denatured $\beta$ lactoglobulin is the initiator. Interaction of $\beta$-lactoglobulin with $\kappa$-casein, present at the exterior of the casein micelle, leads to coating of the casein micelles with $\beta$-lactoglobulin. Interactions of $\beta$-lactoglobulin with cysteine-containing serum caseins might lead to caseinwhey protein aggregates. Additionally, interactions of $\beta$-lactoglobulin with cysteinecontaining whey proteins, such as $\alpha$-lactalbumin and $\beta$-lactoglobulin molecules, result in the formation of whey protein aggregates [118]. Hydrogen bonding and electrostatic and hydrophobic interactions have also been suggested as major forces in whey protein aggregation [119]. To summarize, heat treatment of milk results in a complex mixture of native whey proteins and denatured whey proteins present as whey protein aggregates, casein-whey protein aggregates and whey protein coated casein micelles [118]. The association of denatured whey proteins to casein micelles significantly increases the casein micelle size [114, 119]. According to Pesic et al. [120], after exposing bovine milk to a severe heat treatment $\left(90{ }^{\circ} \mathrm{C} ; 10\right.$ minutes) at natural $\mathrm{pH}(6.71)$, about $30 \%$ of denatured whey proteins were involved in soluble complexes. Figure 4 shows a schematic representation of the effects of heat treatment and subsequent acidification on casein micelles and whey proteins present in skim milk.

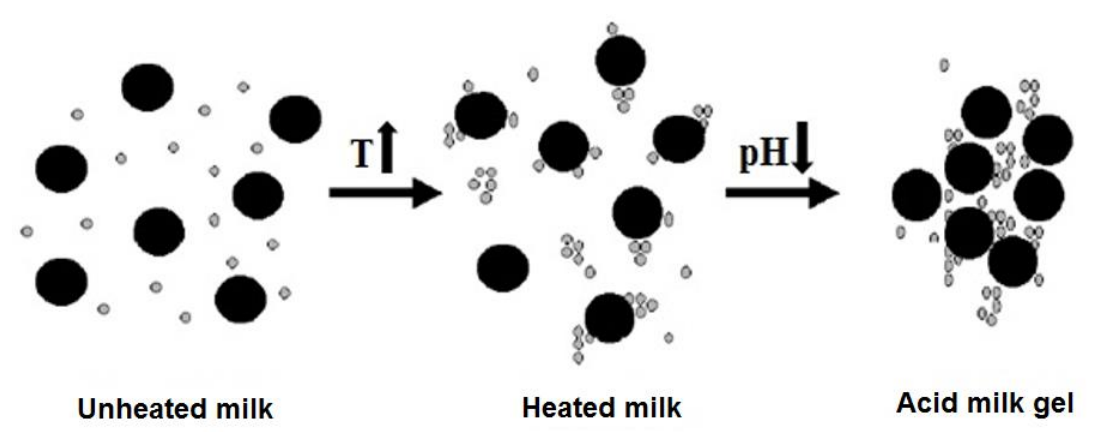

\begin{abstract}
Casein micelle Whey protein
Figure 4. Schematic representation of the heating of skim milk and the subsequent acidification resulting in the formation of a protein network

Source: Adapted from Vasbinderet al. (2003) [118].
\end{abstract}

The extent and rate of denaturation of whey proteins are determined by a number of factors. Amongst these are the $\mathrm{pH}$ value, the ionic strength and the ionic composition, the protein concentration and casein to whey protein ratio of the heat treated whey protein solution, and the duration and temperature of the heat treatment [121].Increasing the $\mathrm{pH}$ above the natural $\mathrm{pH}$ of milk markedly accelerates the rate of denaturation of $\beta$-lactoglobulin. Generally a decrease in the $\mathrm{pH}$ of milk systems prior to heating results in an increased association between the denatured whey proteins and the casein micelle. Even small changes in $\mathrm{pH}$ can shift the distribution of the association of the denatured whey proteins with the casein micelle. For example, at a level of $95 \%$ whey protein denaturation, approximately 
$70 \%$ of denatured whey proteins are associated with the casein micelle at $\mathrm{pH}$ 6.55. This decrease to approximately $30 \%$ when the $\mathrm{pH}$ of milk prior to heating is 6.7 . The difference in association level is reflected in the increase in the casein micelle size when milk is heated at the lower $\mathrm{pH}$ [117]. According to Vasbinder et al. [118], the denatured whey protein aggregates that form contain a ratio of $\alpha$-lactalbumin to $\beta$-lactoglobulin which is representative of the ratio of total denatured whey proteins in milk. $\alpha$-lactalbumin is more easily incorporated in aggregates than it is involved in coating of micelles, while the whey protein coating of the casein micelles clearly contains more $\beta$-lactoglobulin. Vasbinder and de Kruif [122] stated that at high $\mathrm{pH}, \beta$-lactoglobulin- $\beta$-lactoglobulin interactions causing whey protein aggregates are favoured over $\kappa$-casein- $\beta$-lactoglobulin interactions, while $\kappa$ casein- $\beta$-lactoglobulin- $\beta$-lactoglobulin reactions hardly take place. At lower $\mathrm{pH}$, formation of separate whey protein aggregates hardly occurs, but clusters of whey proteins are formed on the surface of the casein micelle. Apparently, at these conditions $\kappa$-casein- $(\beta-$ lactoglobulin $)_{\mathrm{n}}$ interactions are favoured over $\kappa$-casein- $\beta$-lactoglobulin interactions. Figure 5 summarizes the different interactions that take place between casein micelles and denatured whey proteins when different $\mathrm{pH}$ mediums are considered prior to heating.

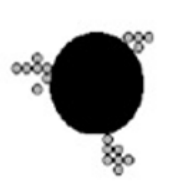

pH 6.35

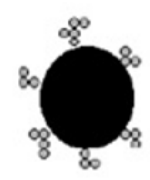

6.45

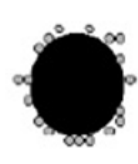

6.55

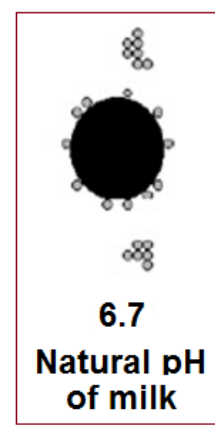

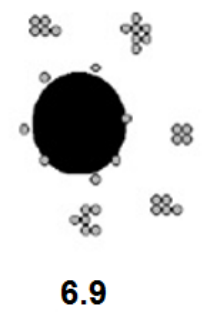

6.9

\section{Casein micelle $\odot$ Whey protein}

Figure 5. Schematic representation of the interactions between casein micelles and whey proteins occurring in milk during heat treatment for $10 \mathrm{~min}$ at $80{ }^{\circ} \mathrm{C}$ at $\mathrm{pH}$ values ranging from 6.35 to 6.9 .

Native whey proteins are not included in the figure. Source: Adapted from Vasbinderet al. (2003) [118].

Anema [40] explains this phenomenon by stating that as the $\mathrm{pH}$ of the milk is increased from about $\mathrm{pH} 6.5$ to $\mathrm{pH} 7.1$ before heating, $\kappa$-casein progressively dissociates from the casein micelles so that, at $\mathrm{pH} 6.5$, the majority of the $\kappa$-casein is associated with the casein micelles, whereas at $\mathrm{pH} 7.1$, about $60-70 \%$ of the $\kappa$-casein is found in the milk serum. As the denatured whey proteins interact with the casein micelles via disulfide bonding with the $\kappa$-casein, this dissociation of $\kappa$-casein probably explains why the association of the whey proteins with the casein micelles is $\mathrm{pH}$-dependent. It is important to note that a more severe heat treatment at a constant $\mathrm{pH}$ will cause more denaturation of whey proteins, but the ratio of denatured whey proteins associated with the casein micelle and present in aggregates will remain constant [118]. Heat-induced interactions of casein micelles and whey proteins are also affected by the casein to whey protein ratio of the milk base. It is believed that $\kappa$-casein 
presents limited number of available binding sites for $\beta$-lactoglobulin association. Thus, when these sites are saturated, denatured whey proteins will interact with each other, increasing the amounts of whey protein aggregates in the system. According to Cho et al. [123], after a heat treatment at $\mathrm{pH}$ 6.7, a maximum number of disulfide bonds between $\kappa$ casein and whey proteins is formed when using a casein to whey protein ratio of $4: 1$ [124]. Calcium ions promote the association of $\beta$-lactoglobulin with casein micelles, perhaps due to the ability of ions to influence the degree of electrostatic attraction or repulsion between $\beta$ lactoglobulin and $\kappa$-casein by providing an ionic environment around the interacting molecules. Additionally, salts could be affecting the reactivity of thiol groups. Furthermore, lactose concentration is a limiting factor for the whey protein denaturation. The glucosyl residues are bound to $\beta$-lactoglobulin via gluconic acid or melibionic acid, making this whey protein fraction stable against heat treatment. Lactose concentrations of milk with normal chemical composition do not have any negative effect on the rate of whey protein denaturation. However, if the lactose level of yogurt milk is increased during standardization, the rate of whey protein denaturation is likely reduced. In order to overcome this handicap, milk should exposed to a higher heat treatment (at $>90{ }^{\circ} \mathrm{C}$ for $10-15 \mathrm{~min}$ ) [41]. The association of denatured whey proteins with micellar caseins on heating gives improved yogurt texture and gel strength [125]. Yoghurt prepared from heated skim milk and 2\% protein from whey protein concentrate had higher storage modulus, firmness, water holding capacity and a denser microstructure than those prepared only from skim milk [126]. On the other hand, it is thought that native whey proteins do not interact with casein micelles during the acidification of unheated milk and act as a destructive filler, or a structure breaker, in acid milk gels [51]. Lee and Lucey [127] reported that yogurt gels made from milk heated at high temperatures $\left[>80^{\circ} \mathrm{C}\right]$ presented a higher cross-linked and branched protein structure with smaller pores than gels made from milk heated at low temperatures [31]. This branched microstructure increases the elasticity, gel strength and water binding capacity of the final gel [38, 121, 127-129]. Therefore, yogurts produced from heated milks will have greater firmness and lower susceptibility to syneresis. According to Sodini et al. [51], a heating that ensures 60 to $90 \%$ of $\beta$-lactoglobulin denaturation generally optimizes both the WHC and the rheological properties of the final gel. On the other hand, a too severe heating generally (above $90 \% \beta$-lactoglobulin denaturation) has a slightly detrimental effect on yogurt's physical properties.

\section{Important factors that define yogurt quality}

Two of the most important parameters that define yogurt quality and determine consumer acceptance are, unquestionably, the textural attributes and the WHC of the gel network [31, 37, 38, 51, 54, 130-132].

\subsection{Rheology}

Textural attributes, including the desired oral viscosity, are very important criteria that determine the identity, quality and consumer acceptance of yogurt [130, 131, 133]. Although texture is related to the sensory perception of a food product, rheology and structure of a product evaluated by instrumental methods also provide relevant information on its textural properties [51]. Skriver et al. [47], Richardson et al. [134], and Stanley and Taylor [135] reported that sensory texture analyses are highly correlated with the rheological properties of stirred yogurt and other semi-solid foods. Due to this fact, rheological properties of milk gels 
are important physical attributes which contribute to the overall sensory perception and functionality of these products [37].

Yogurt is defined as a weak viscoelastic gel system which is unable to keep its structural integrity during high shear $[31,53,67]$. Several authors reported the advantages of using oscillatory dynamic tests over other destructive rheological techniques (e.g., penetrometer, rotational viscometers) to evaluate the rheological characteristics of viscoelastic semisolid foods $[31,53,67,69,136,137]$. The principal advantage of dynamic tests is that they enable measurements to be made without incurring structural damage to the samples. Therefore, this type of tests can be used to relate dynamic rheological parameters to molecular structures [137]. On the other hand, each penetration into or rotation in a gel network causes a breakdown in the elastically effective bonds, and the procedure thus fails to measure the actual physical characteristics of the gel. Once the gel structure is disturbed, it is rarely possible to re-form the gel structure in the same way, because yogurt is a metastable gel and any change in its enthalpic/entropic nature creates irreversible deformation. Thus, any kind of destructive effect may lead to atypical physical properties in the yogurt, and provide erroneous results. Due to this fact, dynamic studies are much more reliable than destructive rheological techniques for studying the physical properties of concentrate yogurt [67]. Consequently, during the last decades, dynamic tests have been widely used to investigate the rheological aspects of acid milk gels [43, 44, 48, 49, 113, 114, 116, 127-129, 138-148]. Small amplitude oscillatory tests are used to compare the rheological aspects of experimental and commercial samples of concentrate yogurt. Small deformation is defined as a small relative deformation which, when applied, does not disrupt the gel network structure, i.e., within the linear viscoelastic region. This type of test involves applying an oscillatory (sinusoidal) stress or strain to the material and measuring the strain or stress responses [31]. The magnitude and phase shift of the transmission depend on the material's viscoelastic nature. Much of the stress is transmitted in highly elastic materials while it is dissipated in frictional losses in highly viscous ones. The phase shift is large for highly viscous materials but small for highly elastic materials [149]. Several rheological parameters are determined in a small amplitude oscillatory rheology test. The storage modulus $\left(\mathrm{G}^{\prime}\right)$ expresses the magnitude of the energy that is stored in the material or recoverable per cycle of deformation (indicates the solid-like properties). The loss modulus (G") is a measure of the energy which is lost as viscous dissipation per cycle of deformation (reflects the liquid-like properties). Therefore, for a perfectly elastic solid, all the energy is stored, that is, $\mathrm{G}^{\prime \prime}$ is zero and the stress and the strain will be in phase. In contrast, for a liquid with no elastic properties, all the energy is dissipated as heat, that is, $\mathrm{G}^{\prime}$ is zero and the stress and the strain will be out of phase by $90^{\circ}$. For a specific food, magnitudes of $G^{\prime}$ and $G^{\prime \prime}$ are influenced by frequency, temperature, and strain. For strain values within the linear range of deformation, $\mathrm{G}^{\prime}$ and $\mathrm{G}^{\prime \prime}$ are independent of strain. The loss tangent $(\tan \delta)$ is the ratio of the energy dissipated to that stored per cycle of deformation and indicates the type of viscoelastic properties in a material. A high $\tan \delta$ value (i.e., G' $>$ G') means that the material has liquid-like behavior $[31,150]$. These parameters are defined as follows:

$$
\begin{aligned}
& \mathrm{G}^{\prime}=\left[\frac{\sigma_{0}}{\gamma_{0}}\right] \cos \delta \\
& \mathrm{G}^{\prime \prime}=\left[\frac{\sigma_{0}}{\gamma_{0}}\right] \sin \delta \\
& \tan \delta=\left[\frac{\mathrm{G} \prime \prime}{G^{\prime}}\right]
\end{aligned}
$$


where $\sigma_{0}$ is the amplitude of the share stress, $\gamma_{0}$ is the amplitude of the strain and $\delta$ is the phase angle difference between the stress and the strain [38, 150, 151]. In acid milk gels, the $\mathrm{G}^{\prime}$ is determined by the number and/or strength of non-relaxing protein bonds (covalent bonds), whereas the $\mathrm{G}^{\prime}$ ' is determined by rapidly relaxing bonds (non-covalent bonds) [53]. The G' and G' are similarly related to the spatial distribution and the number of proteinprotein bonds, which, therefore, suggests that $\tan \delta$ is related to the nature of the protein bonds [69].

\subsection{Whey separation}

Whey separation, i.e., the appearance of whey on the surface of a milk gel, is a common defect in fermented milk products such as yogurt [38, 132]. Whey separation negatively affects consumer perceptions of yogurt, as consumers think there is something microbiologically wrong with the product [31]. Due to this fact, manufacturers try to prevent whey separation by increasing the total solids content of milk, subjecting the milk to a severe heat treatment (to increase whey protein denaturation) or by adding stabilizers such as gelatin, pectin, starches, or gums [37]. Spontaneous syneresisis the usual cause of whey separation [31].Syneresis is defined as shrinkage of a gel and thisoccurs concomitantly with expulsion of liquid or whey separation. Spontaneoussyneresis is contraction of a gel without the application of any external forces(e.g., centrifugation) and is related to instability of the gel network (i.e., largescale rearrangements) resulting in the loss of the ability to entrap all the serumphase [132]. Hence, excessive rearrangements of particles in the gel network are responsible for high levels of whey separation [105]. Previous studies showed that several manufacturing conditions, such as low total solids content (protein content) of the mix, very low acid production $(\mathrm{pH} \geq 4.8)$, excessive heat treatment of the mix, and very high incubation temperatures, promote whey separation [38, 105]. Increasing content of protein by whey protein concentrate addition decreases the syneresis [152]. Whey separation is intimately related to the gel network's microstructure. Extensive rearrangements of protein particles in the gel network may be associated with increased local breakage of weak protein strands that make up the junctions in the network. This may result in the formation of weak spots and a less stable gel network [131]. Several authors reported that a high number of relaxing (noncovalent) protein bonds present in the gel favor rearrangements in the network and results in greater whey separation $[105,116,127,153]$. As the number of non-relaxing (covalent) protein bonds increases, the level of rearrangements in the gel network decreases and a lower level of whey separation is obtained $[105,116,127,154]$. Hence, high $\tan \delta$ values together with low G'values can be correlated with high levels of whey separation [105]. On the other hand, whey separation is also related to the permeability of the gel network. Finer networks with a higher level of cross-links and smaller pores will have less of a tendency to exhibit whey drainage under the force of gravity than coarser, more open structures [145].

\subsection{Clusters formation}

Undesired clusters can have a negative effect on a yogurt's texture. Numerous manufacturing parameters, such as severe heat treatments, excessive whey protein to casein ratios, high incubation temperatures, certain types of starter cultures and the use of excessive amounts of starter culture, are associated with textural defects of stirred yogurt like graininess (particles) or surface roughness (irregularities in the yogurt matrix) [51, 155]. Remeuf et al. [114] reported that graininess can be related to an increase in the casein micelles size caused by the interaction of micelles with denatured whey proteins. Puvanenthiran et al. [145] associated the observed granny texture with the formation of big whey protein aggregates. 
Although manufacturing parameters have a direct influence on the formation of clusters, according to Lee and Lucey [31], stirred yogurts are likely to have clusters of protein aggregates which are presumably created by the collisions and shearing during the mixing process involved in their production.

\section{Conclusions}

Future research should be focused on the production of concentrated yogurt by direct recombination. It offers important advantages over other industrial production methods as it is more environmentally friendly and the product can be more nutritious. Still, rheological properties of recombined concentrated yogurt are different from those of strained yogurt. Usually they form weaker gels than those made by traditional or UF methods. Different dry dairy ingredients (especially with elevated content of whey protein) should be used for production of concentrated yogurt. Such products could be used as supplements of diet for sportsmen and physically active people. In the future it is also crucial to find an effective formulation for producing a recombined non-fat, additive-free type of Greek-style yogurt. Increased whey protein content (in form of whey protein isolate with low content of fat) could solve the problem of weaker texture of non-fat product.

\section{References}

1. Hui Y. H. (2012), Cottage cheese and yogurt: standards, grades, and specifications, Handbook of animal-based fermented food and beverage technology, pp. 319-334, CRC Press, Boca Raton

2. Shah N. (2003), Yogurt. The product and its manufacture. In B. Caballero L. Trugo, \& P.M. Finglas (Eds.), Encyclopedia of Food Science and Nutrition 2 ${ }^{\text {nd }}$, Edition (pp. 6252-6259). Academic Press, London.

3. Tamime A.Y., Hickey M., Muir D.D. (2014), Strained fermented milks - A review of existing legislative provisions, survey of nutritional labelling of commercial products in selected markets and terminology of products in some selected countries, International Journal of Dairy Technology, 67(3), pp. 305-333.

4. Nsabimana C., Jiang B., Kossah R. (2005), Manufacturing, properties and shelf life of labneh: a review, International Journal of Dairy Technology, 58(3), pp. 129-137.

5. Al-Kadamany E., Toufeili I., Khattar M., Abou-Jawdeh Y., Harakeh S., Haddad T. (2002), Determination of shelf life of concentrated yogurt (labneh) produced by in-bag straining of set yogurt using hazard analysis, Journal of Dairy Science, 85(5), pp. 1023-1030.

6. Al Khalaileh N.I., Maghaydah S., Al-Rousan W.M., Ajo R.Y. (2019), Effect of variation in region and seasons on sensory, chemical and microbiological characteristics of Labneh manufactured by traditional methods, Carpatian Journal of Food Science and Technology, 11(1), pp. 32-40.

7. Tamime A.Y., Robinson R.K. (2007), Traditional and recent developments in yoghurt production and related products. In A. Y. Tamime, \& R.K. Robinson (Eds.), Yoghurt: Science and technology $3^{\text {rd }}$ Edition, (pp. 348-367). CRC Press, Boca Raton.

8. Tamime A.Y., Robinson R.K. (1999), Traditional and recent developments in yoghurt production and related products. In A. Y. Tamime, \& R.K. Robinson (Eds.), Yoghurt: Science and technology $2^{\text {nd }}$ Edition, pp. 306-388, CRC Press, Boca Raton.

9. Robinson R.K. (2002), Yoghurt types and manufacture. In P.F. Fox (Ed.), Encyclopedia of Dairy Sciences, pp. 1055-1058, Elsevier Science, Burlington. 
10. Tamime A.Y., Kalab, M., Davies G. (1989), Rheology and microstructure of strained yogurt (labneh) made from cow's milk by three different methods, Food Microstructure, 8(1), pp. 125-135.

11. Salji J.P., Sawaya W.N., Ayaz, M., Mashhadi A. (1987), Production, processing and quality assessment of dairy products in the western province of Saudi Arabia, Milchwissenschaft, 42(1), pp. 27-31.

12. Mahdian E., Tehrani M. M. (2007), Evaluation the effect of milk total solids on the relationship between growth and activity of starter cultures and quality of concentrated yoghurt, American-Eurasian Journal of Agricultural \& Environmental Science, 2(5), pp. 587592.

13. Bayless T.M., Brown E., Paige D.M. (2017), Lactase non-persistence and lactose intolerance, Current Gastroenterology Reports, 19, pp. 23-28.

14. Jorgensen, C.E. ; Abrahamsen, R.K., Rukke, E.O., Hoffmann, T.K., Johansen, A.G. Skeie, S.B. (2019), Processing of high-protein yoghurt - A review, International Dairy Journal, 88, pp. 42-59.

15. Benzech, T., Maingonat, J.F. (1994), Characterization of the rheological properties of yogurt - A review, Journal of Food Engineering, 21(4), pp. 447-472.

16. de Magalhaes, A.U., Goncalves Della Torre, A.C. (2018), Chemical composition and sensory analysis of Greek yogurt traded in the South of the state of Minas Gerais, Journal of CandidoTostes Dairy Institute, 73(1), pp. 10-18.

17. Alirezalu, K., Inacio, R., Hesari, J., Remize, F., Nemati, Z., Saraiva, J.A., Barba, F., Sant'Ana, A., Lorenzo, J.M. (2019), Nutritional, chemical, syneresis, sensory properties, and shelf life of Iranian traditional yoghurts during storage, LWT-Food Science and Technology, 114, 108417.

18. World Health Organization/Food and Agriculture Organization of the United Nations. (2011), CODEX standard for fermented milks (CODEX STAN 243-2003). In: World Health Organization/Food and Agriculture Organization of the United Nations (Ed.), Milk and milk products $2^{\text {nd }}$ Edition (pp. 6-16). World Health Organization/Food and Agriculture Organization of the United Nations, Rome.

19. Auclair, O., Han, Y., Burgos, S.A. (2019), Consumption of milk and alternatives and their contribution to nutrient intakes among Canadian adults: Evidence from the 2015 Canadian Community Health Survey-Nutrition, Nutrients, 11(8), pp. 1948-1957.

20. Hanach N.I., McCullough F., Avery A. (2019), The impact of dairy protein intake on muscle mass, muscle strength, and physical performance in middle-aged to older adults with or without existing sarcopenia: A systematic review and meta-analysis, Advances in Nutrition, 10, pp. 59-69.

21. Salji, J.P. (1991), Concentrated yogurt: a challenge to our food industry, Food Science and Technology Today, 5, pp. 18-19.

22. Chandan, R.C., Kilara, A. (2008), Role of milk and dairy food in nutrition and health. In R. C. Chandan, A. Kilara, \& N.P. Shah (Eds.), Dairy processing and quality assurance, (pp.411428), Wiley-Blackwell, Ames

23. Chryssanthopoulos, C., Maridaki, M. (2009), Nutritional aspects of yogurt and functional dairy products. In F. Yildiz (Ed.), Development and manufacture of yogurt and other functional dairy products, (pp.267-305), CRC Press, Boca Raton.

24. Chandan, R.C., Nauth, K.R. (2012), Yogurt. In Y. H. Hui (Ed.), Handbook of animal-based fermented food and beverage technology, (pp. 213-233), CRC Press, Boca Raton.

25. Drouin-Chartier J.-P., Brassard D., Tessier-Grenier M., Côté J.A., Labonté M.-Č., Desroches S., Couture P., Lamarche B. (2016), Systematic review of the association between dairy product consumption and risk of cardiovascular-related clinical outcomes, Advances in Nutrition, 7, pp. 1026-1040. 
26. Tessier A.-J., Chevalier S. (2018), An update on protein, leucine, omega-3 fatty acids, and vitamin $\mathrm{D}$ in the prevention and treatment of sarcopenia and functional decline, Nutrients, 10 , pp. 1099-1106.

27. Nestel P.J. (2019), Dietary fat and blood pressure, Current Hypertension Reports, 21(2), pp. $17-22$.

28. Canadian Dairy Information Center. (2019), Consumption of Dairy Products, Available at: https://www./dairyinfo.gc.ca/index_e.php?s1=d-fcil\&s2=cons\&s3=conscdn.

29. Statista (2018), Available at: https://www.statista.com/topics/2351/greek-yogurt.

30. Yildiz F. (2009), Overview of yogurt and other fermented dairy products. In F. Yildiz (Ed.), Development and manufacture of yogurt and other functional dairy products pp. 1-45, CRC Press, Boca Raton.

31. Lee W.J., Lucey J.A. (2010), Formation and physical properties of yogurt, Asian-australasian Journal of Animal Sciences, 23(9), pp. 1127-1136.

32. Nauth K.R. (2006), Yogurt. In Y. H. Huy (Ed.), Handbook of food science, technology, and engineering, Vol. 4, pp. 152-1-152-15, CRC Press, Boca Raton.

33. Chandan R.C., O'Rell R.K. (2006), Principles of yogurt processing. In R.C. Chandan, C.H. White, A. Kilara, \& Y. H. Hui (Eds.), Manufacturing yogurt and fermented milks, (pp.). Ames, IA: Blackwell Publishing.

34. Harwalkar V.R., Kalab M. (1986), Relationship between microstructure and susceptibility to syneresis in yogurt made from reconstituted nonfat dry milk, Food Microstructure, 5(2), pp. 287-294.

35. Rohm H., Schmidt W. (1993), Influence of dry matter fortification on flow properties of yogurt. 1. Evaluation of flow curves, Milchwissenschaft, 48(10), pp. 556-560.

36. Mistry V.V., Hassan H.N. (1992), Manufacture of nonfat yogurt from a high milk protein powder, Journal of Dairy Science, 75(4), pp. 947-957.

37. Lucey J.A. (2002), Formation and physical properties of milk protein gels, Journal of Dairy Science, 85(2), pp. 281-294.

38. Lucey J.A., Singh, H. (1998), Formation and physical properties of acid milk gels: a review, Food Research International, 30(7), pp. 529-542.

39. Bhullar Y.S., Uddin M.A., Shah N.P. (2002), Effects of ingredients supplementation on textural characteristics and microstructure of yoghurt, Milchwissenschaft, 57(6), pp. 328-332.

40. Anema S. G. (2008), Effect of milk solids concentration on the gels formed by the acidification of heated pH-adjusted skim milk, Food Chemistry, 108(1), pp. 110-118.

41. Özer B.H. (2009), Strategies for yogurt manufacturing. In F. Yildiz (Ed.), Development and manufacture of yogurt and other functional dairy products, pp. 47-96, CRC Press, Boca Raton.

42. Barreto Penna A.L., Converti A., Nogueira de Oliveira M. (2006), Simultaneous effects of total solids content, milk base, heat treatment temperature and sample temperature on the rheological properties of plain stirred yogurt, Food Technology and Biotechnology, 44(4), pp. $515-518$.

43. Wu S., Li, D., Yang B.L., Mao Z.H., Li, S.J., Bhandari B., Chen X. D. (2009), Effects of incubation temperature, starter culture level and total solids content on the rheological properties of yogurt, International Journal of Food Engineering, 5(2), Article 3.

44. Krzeminski A., Groszhable K., Hinrichs J. (2011), Structural properties of stirred yoghurt as influenced by whey proteins, LWT - Food Science and Technology, 44(10), pp. 2134-2140.

45. Jumah R.Y., Shaker R.R., Abu-Jdayil B. (2001), Effect of milk source on the rheological properties of yogurt during the gelation process, International Journal of Dairy Technology, 54(3), pp. 89-93.

46. Amatayakul T., Sherkat F., Shah N. P. (2006), Physical characteristics of set yoghurt made with altered casein to whey protein ratios and EPS-producing starter cultures at 9 and 14\% total solids, Food Hydrocolloids, 20(2), pp. 314-324. 
47. Skriver A., Holstborg J., Qvist K.B. (1999), Relation between sensory texture analysis and rheological properties of stirred yogurt, Journal of Dairy Research, 66(4), pp.609-618.

48. Peng Y., Serra M., Horne D.S., \& Lucey J.A. (2009), Effect of fortification with various types of milk proteins on the rheological properties and permeability of nonfat set yogurt, Journal of Food Science, 74(9), pp. 666-673.

49. Marafon A.P., Sumi A., Granato D., Nogueira O.M., Alcantara M.R., Tamime A.Y. (2011), Effects of partially replacing skimmed milk powder with dairy ingredients on rheology, sensory profiling, and microstructure of probiotic stirred-type yogurt during cold storage, Journal of Dairy Science, 94(11), pp. 5330-5340.

50. Lucey J.A. (2009), Milk protein gels. In A. Thompson, M Boland, \& Singh, H. (Eds.), Milk proteins from expression to food, (pp. 449-481). Academic Press, New York.

51. Sodini I., Remeuf F., Haddad S., Corrieu G. (2004), The relative effect of milk base, starter, and process on yogurt texture: a review, Critical Reviews in Food Science and Nutrition, 44(2), pp. 113-137.

52. Tamime A.Y., Robinson R.K. (2007), Background to manufacturing practice. In A. Y. Tamime, \& R.K. Robinson (Eds.), Yoghurt: Science and technology $3^{\text {rd }}$ Edition, pp. 13-161, CRC Press, Boca Raton.

53. Özer B.H, Grandison A.S., Robinson R.K. (1998), Rheological properties of concentrated yoghurt (labneh), Journal of Texture Studies, 29(1), pp. 67-79.

54. Abu-Jdayil B., Jumah R.Y., Shaker R.R. (2002), Rheological properties of a concentrated fermented product, labneh, produced from bovine milk: effect of production method, International Journal of Food Properties, 5(3), pp. 667-680.

55. Moineau-Jean A., Champagne C.P., Roy D., Raymond Y., LaPointe G. (2019), Effect of Greek-style yoghurt manufacturing processes on starter and probiotic bacteria populations during storage, International Dairy Journal, 93, pp. 35-44.

56. Yamani M.I., Abu-Jaber M.M. (1994), Yeast flora of labaneh produced by in-bag straining of cow milk set yogurt, Journal of Dairy Science, 77(12), pp. 3558-3564.

57. Tamime A.Y., Robinson R.K. (1988), Fermented milks and their future trends: Part II. Technological aspects, Journal of Dairy Research, 55(2), pp. 281-307.

58. Robinson R.K., Tamime A.Y. (1993), Manufacture of yoghurt and other fermented milks. In R. K. Robinson (Ed.), Modern dairy technology $2^{\text {nd }}$ Edition (Vol. 2), pp.1-48. Elsevier Applied Science Publishers Ltd, London.

59. Özer B.H. (2006), Production of concentrated products. In A. Y. Tamime (Ed.), Fermented milks, pp.128-155, Blackwell Science Ltd, Ames

60. Tamime A.Y. (1993), Yoghurt-based products. In R. Macrae, R. K. Robinson, \& M. J. Sadler (Eds.), Encyclopedia of Food Science, Food Technology and Nutrition, pp. 4972-4977, Academic Press, London.

61. Tamime A.Y. (2003), Yogurt-based products. In B. Caballero, L. Trugo, \& P. Finglas (Eds.), Encyclopedia of Food Science and Nutrition $2^{\text {nd }}$ Edition, pp. 6259-6264, Academic Press, London.

62. Tamime A.Y., Marshall V.M.E. (1997), Microbiology and technology of fermented milks. In B. A. Law (Ed.), Microbiology and biochemistry of cheese and fermented milk $2^{\text {nd }}$ Edition, pp. 57-133, Chapman \& Hall, New York.

63. Tamime A.Y., Robinson R.K., Latrille E. (2001), Yogurt and other fermented milks. In A. Y. Tamime, \& B. A. Law (Eds.), Mechanisation and automation in dairy technology, pp. 152203, CRC Press, Boca Raton.

64. Tamime A.Y., Davies G., Chehade A.S., Mahdi H.A. (1989), The production of labneh by ultrafiltration: a new technology, International Journal of Dairy Technology, 42(2), pp. 3539. 
65. Tamime A.Y., Kalab M., Mahdi H. A. (1991), Microstructure and firmness of labneh (high solids yoghurt) made from cow's, goat's and sheep's milks by a traditional method or by ultrafiltration, Food Structure, 10(1), pp. 37-44.

66. Tamime A.Y., Kalab M., Davies G. (1991), The effect of processing temperatures on the microstructure and firmness of labneh made from cow's milk by the traditional method or by ultrafiltration., Food Structure, 10(4), pp. 345-352.

67. Özer B.H., Robinson R.K., Grandison A.S., \& Bell A.E. (1997), Comparison of techniques for measuring the rheological properties of labneh (concentrated yogurt), International Journal of Dairy Technology, 50(4), pp. 129-133.

68. Özer B.H., Robinson R.K., Grandison A.S., Bell A.E. (1998), Gelation properties of milk concentrated by different techniques, International Dairy Journal, 8(9), pp. 793-799.

69. Özer B.H., Stenning R.A., Grandison A.S., Robinson R.K. (1999), Rheology and microstructure of labneh (concentrated yogurt), Journal of Dairy Science, 82(4), pp. 682-689.

70. Özer B.H., Stenning R.A., Grandison A.S., Robinson R.K. (1999), Effect of protein concentration on the properties and structure of concentrated yogurts, International Journal of Dairy Technology, 52(4), pp. 135-138.

71. El-Samragy Y.A., El-Sayed M.M., Abd-Rabou N.S. (1997), Nutritive value of labneh as affected by processing method, Egyptian Journal of Dairy Science, 25(1), pp. 85-97.

72. Tamime A.Y., Robinson R.K. (1978), Some aspects of the production of concentrated yoghurt (labneh) popular in the Middle East, Milchwissenschaft, 33(4), pp. 209-212.

73. Abou-Donia S.A. (2004), Recent developments in Zabady and Egyptian labneh research: a review, Egyptian Journal of Dairy Science, 32(1), pp. 1-16.

74. Dagher S., Ali-Ghariebeh A. (1985), Effect of pasteurization, centrifugation and additives on the quality of concentrated yoghurt (labneh), Journal of Food Protection, 48(4), pp. 300-302.

75. Rasic J.L. (1987), Yoghurt and yoghurt cheese manufacture, Cultured Dairy Products Journal, 22(4), pp. 6-8.

76. Lehmann H.R., Dolle E., Büker H. (1991), Processing lines for the production of soft cheese $3^{\text {rd }}$ Edition. Westfalia Separator, Oelde.

77. Tamime A.Y., Davies G., Chehade A.S., Mahdi H.A. (1991), The effect of processing temperatures on the quality of labneh made by ultrafiltration, International Journal of Dairy Technology, 44(4), pp. 99-103.

78. Özer B.H, \& Robinson R.K. (1999), The behaviour of starter cultures in concentrated yoghurt (labneh) produced by different techniques, Lebensmittel-Wissenschaft und-Technologie, 32(7), pp. 391-395.

79. El-Samragy Y.A., Zall R.R. (1988), Organoleptic properties of the yoghurt-cheese labneh manufactured using ultrafiltration, Dairy Industries International, 53(3), pp. 27-28.

80. Hofi M.A. (1988), Labneh (concentrated yogurt) from ultrafiltrated milk, Scandinavian Dairy Industry, 2(1), pp. 50-52.

81. Valencia A.P., Doyen A., Benoit S., Margni M., Pouliot Y. (2018), Effect of ultrafiltration of milk prior to fermentation on mass balance and process efficiency in Greek-style yogurt manufacture, Foods, 7(9), pp. 144-149.

82. Gilles J., \& Lawrence R.C. (1981), The manufacture of cheese and other fermented products form recombined milk, New Zealand Journal of Dairy Science and Technology, 16, pp. 1-12.

83. Kjærgaard Jensen G., Nielsen P. (1982), Reviews of the progress of dairy science: milk powder and recombination of milk and milk products, Journal of Dairy Research, 49(3), pp. $515-544$.

84. Zayan A.F., Hassanein A.M., Ragab W. A. (2010), Effect of partial substitution of milk solids with whey protein concentrate powder in "labneh" made by ultrafiltration, Journal of Food and Dairy Science, 1(12), pp. 757-763.

85. Salji J.P., Sawaya W.N., Ayaz M., Mashhadi A. (1987), The dairy industry in the Eastern, Northen, and Southern Provinces of Saudi Arabia, Milchwissenschaft, 42(5), pp. 291-293. 
86. Uduwerella G., Chandrapala J., Vasiljevic T. (2018), Preconcentration of yoghurt base by ultrafiltration for reduction in acid whey generation during Greek yoghurt manufacturing, International Journal of Dairy Technology, pp. 71(1), 71-80.

87. World Health Organization/Food and Agriculture Organization of the United Nations. (2011), CODEX general standard for the use of dairy terms (CODEX STAN 206-1999). In: World Health Organization/Food and Agriculture Organization of the United Nations (Ed.), Milk and milk products $2^{\text {nd }}$ Edition (pp. 176-179). Rome, Italy: World Health Organization/Food and Agriculture Organization of the United Nations.

88. Odet, G. (1990), Fermented recombined milk and lactose intolerance. In International Dairy Federation (Ed.), Recombination of milk and milk products: proceedings of a seminar organized by The International Dairy Federation and The University of Alexandria, 12-16 November 1988. IDF special issue No. 9001, pp. 219-226. International Dairy Federation, Brusseles.

89. Avisar Y.K. (2010), Milk fat globule size, powder hydration time, para- $\square$-casein content and textural properties of recombined white-brined cheese produced by direct recombination system, Journal of Food Processing and Preservation, 34(1), pp. 223-240.

90. Caric M. (2002), Milk powders: types and manufacture. In P.F. Fox (Ed.), Encyclopedia of Dairy Sciences, (pp.1869-1874). Elsevier Science, Ltd, Burlington,

91. Gonzalez-Martinez, C., Becerra, M., Chafer, M., Albors, A., Carot, J.M., \&Chiralt, A. (2002), Influence of substituting milk powder for whey powder on yoghurt quality. Trends in Food Science \& Technology, 13(9-10), pp. 334-340.

92. Guzman-Gonzalez, M., Morais, F., Ramos, M., Amigo, L. (1999), Influence of skimmed milk concentrate replacement by dry dairy-products in a low fat set-type yoghurt model system. I: Use of whey protein concentrates, milk protein concentrates and skimmed milk powder. Journal of the Science of Food and Agriculture, 79(8), pp. 1117-1122.

93. Guzman-Gonzalez, M., Morais, F., Amigo, L. (2000), Influence of skimmed milk concentrate replacement by dry dairy products in a low-fat set-type yoghurt model system. Use of caseinates, co-precipitate and blended dairy powders. Journal of the Science of Food and Agriculture, 80(4), pp. 433-438.

94. Kjærgaard Jensen, G. (1990), Milk powders: specifications in relation to the products to be manufactured. In International Dairy Federation (Ed.), Recombination of milk and milk products: proceedings of a seminar organized by The International Dairy Federation and The University of Alexandria, 12-16 November 1988. IDF special issue No. 9001, pp.104-125, International Dairy Federation, Brusseles.

95. Tong P.S. (2002), Recombined and reconstituted products. In P.F. Fox (Ed.), Encyclopedia of Dairy Sciences, pp.2401-2404, Elsevier Science, Ltd, Burlington.

96. Kneifel W. (1993), Recombined and filled milks. In R. Macrae R.K. Robinson, \& M.J. Sadler (Eds.), Encyclopedia of Food Science, Food Technology and Nutrition (pp.4921-4926). Academic Press, London.

97. Nichols J.G., Kozak J.J. (1990), Water for reconstitution. In International Dairy Federation (Ed.), Recombination of milk and milk products: proceedings of a seminar organized by The International Dairy Federation and The University of Alexandria, 12-16 November 1988. IDF special issue No. 9001, pp. 87-103, International Dairy Federation, Brusseles.

98. Christensen P., Colding H. (1988), Recombined cheese, North European Food and Dairy Journal, 54(3), pp. 99-104.

99. Motaleb A. (1990): Milk recombination in Egypt. In International Dairy Federation (Ed.), Recombination of milk and milk products: proceedings of a seminar organized by The International Dairy Federation and The University of Alexandria, 12-16 November 1988. IDF special issue No. 9001, pp. 9-15, Brusseles, Belgium: International Dairy Federation.

100. Schulthess W. (1990), Recombination of milk in Kenya. In International Dairy Federation (Ed.), Recombination of milk and milk products: proceedings of a seminar organized by The 
International Dairy Federation and The University of Alexandria, 12-16 November 1988. IDF special issue No. 9001, pp.23-24, International Dairy Federation, Brusseles.

101. Borland P.A. (1990), The application of recombination technology in Zimbabwe's dairy industry. In International Dairy Federation (Ed.), Recombination of milk and milk products: proceedings of a seminar organized by The International Dairy Federation and The University of Alexandria, 12-16 November 1988. IDF special issue No. 9001, pp. 34-37, International Dairy Federation, Brusseles.

102. Ketulo M. (1990), Recombination of milk in Malawi. In International Dairy Federation (Ed.), Recombination of milk and milk products: proceedings of a seminar organized by The International Dairy Federation and The University of Alexandria, 12-16 November 1988. IDF special issue No. 9001, pp. 53-54, International Dairy Federation, Brusseles.

103. EzzatJaafar M., Seppala M.Y. (1990), The dairy industry in Kuwait. In International Dairy Federation (Ed.), Recombination of milk and milk products: proceedings of a seminar organized by The International Dairy Federation and The University of Alexandria, 12-16 November 1988. IDF special issue No. 9001, pp. 55-57, International Dairy Federation, Brusseles.

104. Staal P. (1990), Conclusions and recommendations of the seminar. In International Dairy Federation (Ed.), Recombination of milk and milk products: proceedings of a seminar organized by The International Dairy Federation and The University of Alexandria, 12-16 November 1988. IDF special issue No. 9001, pp. 364-365, International Dairy Federation, Brusseles.

105. Lucey J.A. (2001), The relationship between rheological parameters and whey separation in milk gels, Food Hydrocolloids, 15(4), pp. 603-608.

106. Roefs S.P.F. M., van Vliet T. (1990), Structure of acid casein gels 2. Dynamic measurements and type of interaction forces, Colloids and Surfaces, 50, pp. 161-175.

107. Schmidt D.G. (1982), Association of casein and casein micelle structure. In P. F. Fox (Ed.), Developments in dairy chemistry. 1. Proteins, (pp. 61-86). Applied Science Publishers, London.

108. Walstra P. (1990), On the stability of casein micelles, Journal of Dairy Science, 73(8), pp. 1965-1979.

109. Holt C. (1992), Structure and stability of bovine casein micelles, Advances in Protein Chemistry, 43, pp. 63-151.

110. Horne D.S. (1998), Casein interactions: casting light on the black boxes, the structure in dairy products. , International Dairy Journal, 8(3), pp. 171-177.

111. Horne D.S. (2002), Casein and micellar structure. In H. Roginski, P. F. Fox, \& J. W. Fuquay (Eds.), Encyclopedia of Dairy Sciences, pp. 1902-1909, Academic Press, London

112. Horne D.S. (2009), Casein micelle structure and stability. In A. Thompson, M. Boland, \& Singh, H. (Eds.), Milk proteins from expression to food, pp. 133-162, Academic Press, New York.

113. Ozcan T., Horne D., Lucey J.A. (2011), Effect of increasing the colloidal calcium phosphate of milk on the texture and microstructure of yogurt, Journal of Dairy Science, 94(11), pp. 5278-5288.

114. Remeuf F., Mohammed S., Sodini I., Tissier J.P. (2003), Preliminary observations on the effects of milk fortification and heating on microstructure and physical properties of stirred yogurt, International Dairy Journal, 13(9), pp. 773-782.

115. Lucey J.A. (2004), Formation, structural properties and rheology of acid-coagulated milk gels. In P. F. Fox, P. L. H. McSweeney, T. M. Cogan, \& T. P. Guinee (Eds.), Cheese Chemistry, physics and microbiology $3^{\text {rd }}$ Edition, pp. 105-122, Elsevier Academic Press, San Diego. 
116. Lee W. J., Lucey J.A. (2004), Structure and physical properties of yogurt gels: effect of inoculation rate and incubation temperature, Journal of Dairy Science, 87(10), pp. 31533164.

117. Augustin M.A., Udabage P. (2007), Influence of processing on functionality of milk and dairy proteins, Advances in Food and Nutrition Research, 53, pp. 1-38.

118. Vasbinder A.J., Alting A.C., de Kruif. K.G. (2003), Quantification of heat-induced caseinwhey protein interactions in milk and its relation to gelation kinetics, Colloids and Surfaces B, Biointerfaces, 31(1), pp. 115-123.

119. Anema S.G., Li Y. (2003), Effect of $\mathrm{pH}$ on the association of denatured whey proteins with casein micelles in heated reconstituted skim milk, Journal of Agricultural and Food Chemistry, 51(6), pp. 1640-1646.

120. Pesic M.B., Barac B.M., Stanojevic S.P., Ristic N.M., Macej O.D., Vrvic M.M. (2012), Heat induced casein-whey protein interactions at natural $\mathrm{pH}$ of milk: a comparison between caprine and bovine milk, Small Ruminant Research, 108(1), pp. 77-86.

121. Kessler H.-G., Beyer H.-J. (1991), Thermal denaturation of whey proteins and its effect in dairy technology, International Journal of Biological Macromolecules, 13(3), pp. 165-173.

122. Vasbinder A.J., de Kruif C.G. (2003), Casein-whey protein interactions in heated milk: the influence of pH, International Dairy Journal, 13(8), pp. 669-677.

123. Cho Y.H., Singh H., Creamer L. K. (2003), Heat-induced interactions of $\beta$-lactoglobulin A and \& -casein B in a model system, Journal of Dairy Research, 70(1), pp. 61-71.

124. Gunasekaran S., Solar O. (2012), Heat-induced casein-whey protein interactions. In N. S. Hettiarachchy, K. Sato, M. R. Marshall, \& A. Kannan (Eds.), Food proteins and peptides. Chemistry, functionality, interactions, and commercialization, pp. 199-228, CRC Press, Boca Raton.

125. Law A.J.R. (1996), Effects of heat treatment and acidification on the dissociation of bovine casein micelles, Journal of Dairy Research, 63(1), pp. 35-48.

126. Mokoonlall A., Nobel S., Hinrichs J. (2016), Post-processing of fermented milk to stirred products: Reviewing the effects on gel structure, Trends in Food Science and Technology, 54, pp. 26-36.

127. Lee W.J., Lucey J.A. (2004), Rheological properties, whey separation, and microstructure in set-style yogurt: effects of heating temperature and incubation temperature, Journal of Texture Studies, 34(5-6), pp. 515-536.

128. Lucey J.A., Munro P.A., Singh H. (1999), Effects of heat treatment and whey protein addition on the rheological properties and structure of acid skim milk gels, International Dairy Journal, 9(3-6), pp. 275-279.

129. Lucey J.A., Tamehana M., Singh, H., Munro P.A. (1998), Effect of interactions between denatured whey proteins and casein micelles on the formation and rheological properties of acid skim milk gels, Journal of Dairy Research, 65(4), pp. 555-567.

130. Abu-Jdayil B., Shaker R.R., Jumah R.Y. (2000), Rheological bahavior of concentrated yogurt (Labneh), International Journal of Food Properties, 3(2), pp. 207-216.

131. Lee W.J., Lucey J.A. (2006), Impact of gelation conditions and structural breakdown on the physical and sensory properties of stirred yogurts, Journal of Dairy Science, 89(7), pp. 2374-2385.

132. Lucey J.A., Munro P. A., Singh H. (1998), Whey separation in acid skim milk gels made with glucono- $\delta$-lactone: effects of heat treatment and gelation temperature, Journal of Texture Studies, 29(4), pp. 413-426.

133. Schmidt C., Mende S., Jaros D., Rohm H. (2016), Fermented milk products: effects of lactose hydrolysis and fermentation conditions on the rheological properties, Dairy Science \& Technology, 96(2), pp. 199-211. 
134. Richardson R.K., Morris E.R., Ross-Murphy S.B., Taylor L.J., Dea I.C.M. (1989), Characterization of the perceived texture of thickened systems by dynamic viscosity measurements, Food Hydrocolloids, 3(3), pp. 175-191.

135. Stanley N. L., Taylor L. J. (1993), Rheological basis of oral characteristics of fluid and semisolid foods: a review, ActaPsychologica, 84(1), pp. 79-92.

136. Bylund, G. (1995), Dairy processing handbook, Tetra Pak Processing Systems AB, Lund.

137. Gunasekaran S., \&Ak M.M. (2000), Dynamic oscillatory shear testing of foods - selected applications, Trends in Food Science \& Technology, 11(3), pp. 115-127.

138. Damin M.R., Oliveira M.N., Alcantara M. R., Nunes A.P. (2009), Effects of milk supplementation with skim milk powder, whey protein concentrate and sodium caseinate on acidification kinetics, rheological properties and structure of nonfat stirred yogurt, LWTFood Science and Technology, 42(10), pp. 1744-1750.

139. Marafon A.P., Sumi A., Alcantara M.R., Tamime A.Y., Nogueira O. M. (2011), Optimization of the rheological properties of probiotic yoghurts supplemented with milk proteins, LWT - Food Science and Technology, 44(2), pp. 511-519.

140. Oliveira M.N., Sodini I., Remeuf F., Corrieu G. (2001), Effect of milk supplementation and culture composition on acidification, textural properties and microbiological stability of fermented milks containing probiotic bacteria, International Dairy Journal, 11(11), pp. 935942.

141. Sodini I., Lucas A., Tissier J.P., Corrieu G. (2005), Physical properties and microstructure of yoghurts supplemented with milk protein hydrolysates, International Dairy Journal, 15(1), pp. 29-35.

142. Sodini, I., Mattas, J., Tong, P.S. (2006), Influence of pH and heat treatment of whey on the functional properties of whey protein concentrates in yoghurt. International Dairy Journal, 16(12), pp. 1464-1469.

143. Vlahopoulou I., Bell A.E., Wilbey A. (2001), Effects of starter culture and its expolysaccharides on the gelation of glucono- $\delta$-lactone-acidified bovine and caprine milk, International Journal of Dairy Technology, pp. 54(4), 135-140.

144. Vlahopoulou I., Bell A. E. (1993), Effect of various starter cultures on the viscoelastic properties of bovine and caprine yogurt gels, International Journal of Dairy Technology, 46(2), pp. 61-63.

145. Puvanenthiran A., Williams R.P.W., Augustin M.A. (2002), Structure and visco-elastic properties of set yoghurt with altered casein to whey protein ratios, International Dairy Journal, 12(4), pp. 383-391.

146. Lucey J.A., Teo C.T., Munro P.A., Singh H. (1997), Rheological properties at small (dynamic) and large (yield) deformations of acid gels made from heated milk, Journal of Dairy Research, 64(4), pp. 591-600.

147. Lucey J.A., Van V.T., Grolle K., Geurts T., Walstra P. (1997), Properties of acid casein gels made by acidification with glucono- $\delta$-lactone. 1 . Rheological Properties, International Dairy Journal, 7(6-7), pp. 381-388.

148. Cho Y. H., Lucey J. A., Singh H. (1999), Rheological properties of acid milk gels as affected by the nature of the fat globule surface material and heat treatment of milk, International Dairy Journal, 9(8), pp. 537-545.

149. Sahin S, Sumnu S.G. (2006), Rheological properties of foods. In S. Sahin, \& S. G. Sumnu (Eds.), Physical properties of foods, pp. 39-106, Springer Science, New York.

150. Rao M.A. (2007), Measurement of flow and viscoelastic properties. In M.A. Rao (Ed.), Rheology of fluid and semisolid foods, pp. 59-151, Springer Science, New York.

151. Roefs S.P.F.M., de Groot-Mostert, A.E.A., van Vliet T. (1990), Structure of acid casein gels 1. Formation and model of gel network, Colloids and Surfaces, 50, pp. 141-159.

152. Yildiz-Akgul F. (2018), Enhancement of torba yoghurt with whey protein isolates, International Journal of Dairy Technology, 71(4), pp. 898-905. 
153. van Vliet T., Dijk H.J.M., Zoon P., Walstra P. (1991), Relation between syneresis and rheological properties of particle gels, Colloid \& Polymer Science, 269(6), pp. 620-627.

154. Weidendorfer K., Bienias A., Hinrichs J. (2008), Investigation of the effects of mechanical post-processing with a colloid mill on the texture properties of stirred yogurt, International Journal of Dairy Technology, 61(4), pp. 379-384.

155. Kucukcetin A. (2008), Effect of heat treatment and casein to whey protein ratio of skim milk on graininess and roughness of stirred yoghurt, Food Research International, 41(2), pp. $165-171$. 